\title{
TOWARD A HISTORY OF THE AMERICAN RULE ON ATTORNEY FEE RECOVERY
}

\author{
JOHN LEUBSDORF*
}

I

\section{INTRODUCTION}

In a sense, the American rule has no history. As far back as one can trace, courts in this country have allowed winning litigants to recover their litigation costs from losers only to the extent prescribed by the legislature. ${ }^{1}$ But closer examination reveals that the justification of this rule and its significance in the economy of litigation have varied over the years. Indeed, there may be too much history to handle: the path leads to the study of aspects of procedure, remedies, and professional responsibility which interact with fee rules, and beyond that into the uncharted finances of the American bar. This terrain is also obscured by the peculiar reluctance of the bench and bar either to justify or to change a law of costs which required successful litigants to bear most of the expense of vindicating themselves.

This article will sketch the history of attorney fee recovery in the United States. During the late colonial period, legislation provided for fee recovery as an aspect of comprehensive attorney fee regulation. But this regulatory scheme did not long survive the Revolution. During the first half of the nineteenth century, lawyers freed themselves from fee regulation and gained the right to charge clients what the market would bear. As a result, the right to recover attorney fees from in opposing party became an unimportant vestige. This triumph of fee contracts between lawyer and client as the financial basis of litigation prepared the way for legislators and judges to proclaim the principle that one party should not be liable for an opponent's legal expenses.

Yet even as this principle appeared, exceptions began to develop. As the twentieth century arrived, so did somewhat disturbed commentators, who sought either to justify or to modify the rule of nonrecovery in light of its supposed tendency to encourage or discourage worthy cases. In accordance with this Progressive emphasis on social engineering, courts reshaped fee rules so as to ladle out incentives to those who brought worthy litigation, and to discourage bad faith suits. But judicial and scholarly tinkering have faded into insignificance in the last two decades, as legislatures crashed onto the scene, knocking holes in the rule forbidding fee recovery that they themselves originally shaped. The resulting rise of fee

\footnotetext{
Copyright (C) 1984 by Law and Contemporary Problems

* Professor, Boston University School of Law. I appreciate the help and support of Thomas Rowe, Aviam Soifer, Kenneth Simons, and Kathleen Sullivan.

1. See, e.g., Arcambel v. Wiseman, 3 U.S. (3 Dall.) 306 (1796).
} 
recovery for prevailing plaintiffs (but not prevailing defendants) is the most dramatic change in the legal arrangements for financing litigation since lawyers freed themselves from fee regulation in the early nineteenth century.

If the picture to be sketched here is accurate, earlier investigators have not uncovered the full story of the American rule. Professor Ehrenzweig's ingenious theory that the New York legislature fixed reasonable fee scales in 1848 but then forgot to raise them as times changed ${ }^{2}$ comes up against clear evidence that, for several decades before 1848, lawyers and judges were well aware that the fees recoverable by a prevailing party were absurdly small compared to what clients paid their lawyers. ${ }^{3}$ And Ehrenzweig fails to ask a vital question: why did a legislature stuffed with lawyers neglect to increase fee scales of such apparent importance to the bar?

Explanations which rely on hostility to lawyers ${ }^{4}$ or frontier individualism ${ }^{5}$ come closer to the mark: these ideological factors were important, though neither suffices by itself to explain what happened. Finally, the Supreme Court's suggestion $^{6}$ that prevailing parties were denied attorney fees so that poor plaintiffs would not be deterred from filing suit by the prospect of paying fee awards is not only questionable economics but also a pure anachronism. Such explanations did not appear before the twentieth century.

\section{Colonial Legislation}

During much of the eighteenth century, virtually all the colonies tried to regulate attorney fees by statute. ${ }^{7}$ To be effective, such legislation had to prescribe both the fees a lawyer could charge his client and those that could be recovered from a defeated adversary. ${ }^{8}$ The laws governing attorney fee awards, in other

2. Ehrenzweig, Reimbursement of Counsel Fees and the Great Society, 54 CALIF. L. REV. 792, 798-800 (1966); Ehrenzweig, Shall Counsel Fees Be Allowed?, 26 CAL. ST. B.J. 107 (1951); see Goodhart, Costs, 38 YALE L.J. 849, 873-74 (1929).

3. See infra text accompanying notes 23-26.

4. Goodhart, supra note 2 , at 873 .

5. Note, Attomey's Fees: Where Shall the Ullimate Burden Lie?, 20 VAND. L. REV. 1216, 1220-21 (1967).

6. See Fleischmann Distilling Corp. v. Maier Brewing Co., 386 U.S. 714, 718 (1967). The sources cited in this and notes 2 and 5 are collected in Nussbaum, Attorney's Fees in Public Interest Litigation, 48 N.Y.U. L. REV. 301, 311-13 nn. 31 \& 40-43 (1973).

7. See 1 A.-H. Chroust, The Rise of the Legal Profession in America $85-327$ (1965).

8. Colonial legislation varied over the years and is imperfectly indexed, so that the author's verification of this assertion depends too much on Chroust's work, see supra note 7, and too little on primary sources. Chroust's quotations and descriptions make it clear that -at least during the later colonial period-fee regulation in Massachusetts, New Hampshire, New York, Virginia, and North Carolina fixed what a lawyer could receive from a client at the same level as what he could recover as costs. Id. at 86-89, 129-32, 159-60, 271-72, 317-19. On Virginia, see also statutes cited infra notes 8 \& 24. On New York, see also Klein, The Rise of the New York Bar: The Legal Career of William Livingston, 15 WM. \& MARY Q. 334, 341, 343 (1958) and infro note 20. Chroust's description of six other colonies (Rhode Island, New Jersey, Pennsylvania, Maryland, South Carolina, and Georgia) refers to fee regulation but not to cost regulation. 1 A.H. Chroust, supra note 7, at 41, 139, 197, 213, 255, 327. Delaware (although Chroust does not mention its fee regulation) also falls in this category. LAWS OF THE GOVERNMENT OF NEW-CASTLE, KENT AND Sussex Upon Delaware 255, 264 (Phila. 1741), reprinted in The Earlest Printed Laws of Delaware 1704-1741, at 9-291 (J. Cushing comp. 1978). It seems plausible that when the legislature had fixed the fees to be charged clients, the same amounts would be used in court costs awards, particularly when there was 
words, served less as a way to shift or not shift fees from one party to another than as a way to limit the amount of those fees. Once the fee was set, it was taken for granted that it could be recovered from a losing party. As a Virginia statute noted, "it is, unreasonable that the party who prevails . . . should be subject to the payment of a greater fee to his lawyer than he can recover from the adverse party."

Commentators have usually ascribed this legislation to unreasonable antilawyer hostility, and there is no question that hostility to lawyers existed. Fee regulation, for instance, often followed attempts to ban lawyers entirely. ${ }^{10}$ Sometimes attacks on lawyers reflected hostility to their links to the government, or later to their mercantile clients. " But hostility may not have been a necessary cause of regulation; colonial legislatures regulated many parts of the economy. ${ }^{12}$ That lawyers sometimes complained of low fees ${ }^{13}$ scarcely proves that fees were unreasonably low.

It is not clear what practical effect the fee statutes had. John Adams managed to do pretty well, collecting substantial sums by way of "gifts" and charges for

no other legislation regulating court costs. The author has found nothing to rebut this presumption, and in each colony the statutes give it some support. Act of February 18, 1747/48, in 3 LAWS OF THE ROYAL COLONY OF NEW JERSEY 83, 90-94 (B. Bush 1980) (fee regulation act also provides that bills of costs may be retaxed to eliminate charges for work not done; title of act refers to cost taxation); Act of June 3, 1715, $\S 10$, in 1 The Laws of Maryland, ch. 48 (Annapolis 1799) (fee regulation act provides that fees are to be levied on execution); see Day, Lawyers in Colonial Maryland, 1660-1715, 17 AM. J. LEGAL HIST. 145, 155-56 (1973) (describing fee regulation by statute and court rule); Act of March 15, 1725, A CoMPlEAT ColleCTION OF LAWS OF MARYLAND 283, 308 (Annapolis 1727) (fee regulation act provides that attorney shall not be allowed a fee for prosecuting suit of his own); Act of December 18, 1792, A DiGEST OF THE LAwS Or The State of Georgia 471, 476 (Phila. 1800), reprinted in 2 The First Laws of the State of Georgia 476 (J. Cushing comp. 1981) (fee regulation act provides that, when defendant prevails, he, instead of plaintiff's attorney, shall recover the fee); Act of March 17, 1785, $\$ 61$, The Public Laws OF THE STATE OF SOUth Caroliva 366, 389 (Phila. 1790), reprinted in The First LaWs of the State of South CaroLINA 389 (J. Cushing comp. 1981) (county courts: fee to be recovered as costs; attorney forbidden to charge more); see also The Laws of the Province of Pennsylvania, c.280, at 328, 337 (Phila. 1728) (at torney must file warrant of attorney to be allowed fee in bill of costs); Act of June 15, 1793, $\$ \$ 18,35-37$, in 2 LAWS OF THE STATE OF Delaware 1116, 1122.23 (Newcastle 1797), reprinted in 2 THE First LAWS OF THE State of Delaware 1122-23 (J. Cushing comp. 1981). (Fee regulation act provides that fees will be included in bill of costs and enforced by execution.) The one remaining colony is Connecticut, which regulated recovery of attorney fees as costs but did not explicitly forbid lawyers to charge their own clients more. Yet even there the statutes suggest that the fee limits applied to client charges. ACTS AND LAWS OF THE STATE OF CONNECTICUT IN AMERICA 10-11, 63-65 (New London 1784), reprinted in The First LaWs of the State of Connecticut 63-65 (J. Cushing comp. 1982).

9. $1778 \mathrm{Va}$. Acts, ch. $14, \S 5$, in A Collection of all Such Public ACTs . . AS ARE NOW IN FORCE 84 (Richmond 1785), reprinted in THE FIRST LAwS OF THE STATE OF ViRgINIA 84 (J. Cushing comp. 1982).

10. E.g., L. Friedman, A History of American Law $81-84$ (1973); 1 A.-H.Chroust, supta note 7, passim; see R. Ellis, The JeFrersonian Crisis 111-16, 123-25, 177 (1971) (discussing post-Revolution attitudes); J. Aiken, Utopianism and the Emergence of the Colonial Legal Profession: New York 16641710, A Test Case (Univ. of Rochester, 1967) (unpublished thesis).

11. A. Roeber, Faithrul Magistrates and Republican Lawyers $32-72$ (1981); D. Szatmary, Shays' Rebellion: The Making or an AgraRian Insur rection (1980); see Presser, An Introduction to the Legal History of Colonial New Jersey, 7 RuT.-CAM. L. REV. 262, 324-27 (1976).

12. O. Handlin \& M. Handlin, Commonwealth 64-75 (rev. ed. 1969); J. Hughes, Social Control in the Colonial Economy (1976); M. Heath, Constructive Liberalism 46-63 (1954); 1 F. PaCkard, History of MEdicine in THE United States 164-65 (1963) (medical fee regulation in Virginia).

13. 1 A.-H. Chroust, supra note 7, at 159-60, 255-56. 
legal services not mentioned in the statutory scale. ${ }^{14}$ If his finances were typical-and of course he was a leading lawyer in an unusually well-developed bar-a gap was already opening between the fees lawyers could collect from their clients and the fees they could collect from opponents. Fees collected from opponents were administered by the courts and therefore offered relatively little opportunity to evade statutory regulation, and in any event only those who prevailed in litigation could reap them. Clients were a more promising source of wealth.

Fee recovery by colonial lawyers resembled practice in England to some extent, but with an important difference. In both countries the prevailing party recovered attorney fees as part of the costs, and the right to recovery was grounded on statute. ${ }^{15}$ In England, fees recoverable from an opponent and those chargeable to a client were both subject to taxation by the court, ${ }^{16}$ although not necessarily on the same scale. ${ }^{17}$ The English scales, however, were not set by statute, but by customs regulating the charge for each item of an attorney's services. ${ }^{18}$ Attorney fees were therefore much like fees paid to court clerks. Members of both groups were in part public servants and in part private entrepreneurs. Both performed duties essential to the operation of the courts, and were, at least in theory, regulated by judges. But lawyers and clerks were also in business for themselvesclerks at that time bought their offices and lived on their fees ${ }^{19}$ - and both were careful to collect fees for each item of service.

The colonies did not import this system, perhaps because the requisite customs were left in England together with the elaborate professional and procedural

14. 1 Legal Papers of John Adams lxix-lxxii (L. Wroth \& H. Zobel eds. 1965). After the Revolution, some Massachusetts lawyers boosted fees by delaying and multiplying proceedings. AUSTIN, OBSERvations on the Pernicious Practice of the Law 56-57 (Boston 1786), reprinted in 13 Am. J. Legal HIST. 244, 295 (1969); R. Ellis, supra note 10, at 186 (1971). One historian reports contemporary charges that colonial southern lawyers took unlawful fees, but does not find the charges supported by surviving records. Eaton, A Mirror of the Southem Colonial Lawyer: The Fee Books of Patrick Henry, Thomas Jefferson, and Waightstill Avery, 8 WM. \& MARY Q. (3d ser.) 520 (1951).

15. 3 W. Blackstone, Commentaries on the Law of England 399-401 (London, 1765-69); 1 M. BACON, ABRIDGEMENT 511 (4th ed. London 1778)(costs not recoverable at common law, but only by statute).

16. Stat. 2 Geo. 2, ch. $23, \S 23$ (1729)(right of client to have attorney fee taxed by court); W. TIDD, The LaW of COSTS IN Civil ACTIONS 74-76, 86-103 (London 1793)(taxation procedures).

17. J. SAYer, The Law of Costs 327-28 (2d ed. London 1777) refers to taxation "as between Party and Party" and "as between Attorney and Client." In later English usage, these two phrases denote respectively less and more liberal approaches to taxing costs. But see M. BIRKS, GENTLEMEN OF THE LAW 222 (1960) (even before the 1729 statute, bills to clients were modelled "on what the court would have ordered an unsuccessful party to pay [opposing party]').

18. E.g., J. Palmer, The Attorney and Agent's New Table of Costs (London 1812); see Sayer, supra note 17, at 321-22 (contract for daily fee does not bind client). Barristers were not so regulated: they received fees (called honoraria, theoretically gifts and usually paid in advance) from the solicitors who retained them. G. Holmes, Augustan England 130-32 (1982); 3 W. Blackstone, supra note 15, at 28; 1 J. Jeaffreson, A BoOK About LaWyers 219-33 (2d ed. 1867). The solicitor then recovered the fee from his own client or the losing opposite party. See J. PALMER, supra, at 5, 9 (counsel payment included in bills of costs).

19. See $1 \mathrm{~W}$. Holdsworth, A History of English Law 246-62 (7th ed. 1956). For the incredible accumulation of fees claimed by court functionaries, see LISTS, ACCOUNTS AND TABLES OF FEes (London 1730) and Lists of THE OfFICERs and THEIR Deputies (London 1731), in 13 House Or Commons Sessional Papers of the Eighteenth Century 297-310, 357-374 (S. Lambert ed. 1975). 
mechanism to which they were linked. ${ }^{20}$ Colonists did not need, and could not afford, the elaborate English system. But it also may be that attempts to separate the private and public realms had progressed further in this country than in England. ${ }^{21}$ Although legislatures in the colonies often included attorney fees among those of clergy and other government officers, ${ }^{22}$ lawyers here did not fade into the antique complexities of the English court system. They were already coming forward as private profit-seekers, and the old regulatory mechanism was already starting to apear as oppressive government control. After the Revolution, lawyers succeeded in freeing themselves for all practical financial purposes from that control.

\section{The American Rule Emerges}

The essence of the American rule is that prevailing parties pay more in attorney's fees than they recover in costs from the defeated party. This discrepancy already existed during the early nineteenth century. But for lawyers and judges of that time, what called for attention was not the low level of costs recovery. That had always existed, and was not challenged. Lawyers did, however, challenge the legislative limits on what they could charge their own clients. Once these limits were evaded or repealed, the American rule became institutionalized because attorneys no longer had to push to recover their fees from the defeated party.

It is easier to say when the gap between costs awards and client fees was publicly recognized than to spot when it came into existence. As already noted, we do not know to what extent colonial lawyers were able to evade fee regulation. But, as regulatory statutes were repealed ${ }^{23}$ or forgotten, higher fees came out into the open. In 1792, a Massachusetts bar association adopted a minimum fee schedule more than twice as high as the scale used for costs awards. ${ }^{24}$ By the 1820's and

20. The colonial vice-admiralty courts did import much of the English system, and as a result merchants shunned them as too expensive. M.H. SMITH, THE WR ITS OF ASSISTANCE CASE 166-68 (1978).

21. On the growth of the public-private distinction, see Frug, The City as a Legal Concept, 93 HARv. L. REV. 1057, 1094-1 109 (1980); Kennedy, The Structure of Blackstone's Commentaries, 28 Buffalo L. REv. 209, 286-89 (1979); Horwitz, The History of the Public/Private Distinction, 130 U. PA. L. REv. 1423 (1982). The blur of the private and public realms had not disappeared from the colonies. Ministers, for example, were still paid out of local taxes, at least in New England, while on the other hand government service was often regarded as private property. D. SCOTT, FROM OfFICE TO PROFEssion 1-4 (1978); Nelson, Officholding and Power Wielding: An Analysis of the Relationship between Sinucture and Style in American Administrative History, $10 \mathrm{~L}$. \& SOC'Y REV. 187, 194-95 (1976).

22. The Public Laws of the State of Rhode Island and Providence Plantations 212-24 (Providence 1798), reprinted in The First Laws of THE STate of RhOde IsLand (J. Cushing comp. 1983); Acts Passed by The General Assemby of South Carolina 3, 9-13, 23 (1743)(also fixing the sexton's fee for digging a grave); statutes cited supra note 8 . The colonists insisted that official fees constituted a sort of tax, and could therefore be set only by the colonial legislature. R. MOTT, DUE PROCESS OF LAW 119-22 (1926).

23. For postrevolutionary fee legislation, see 1 A.-H. CHROUST, supra note 7, at 232-77.

24. G. Gawalt, The Promise of Power 91 (1979). Similarly, in 1795, Alexander Hamilton was receiving litigation retainers of fifty dollars and up, although the statutory retaining fee was at most thirty shillings. Act of April 18, 1785, 2 Laws OF THE STATE OF NEW YORK 124-38 (1886); 5 THE LAW PRACtice of Alexander Hamilton 9-10, 21 (J. Goebel \& J. Smith ed. 1981). (At this time, thirty shillings 
1830's, courts were recognizing vast discrepancies between costs awards and usual fees. ${ }^{25}$ By the 1840's, at least one layman was criticizing the gap. ${ }^{26}$

Courts gave little attention to justifying the low level of attorney fees included in court costs. Indeed, they apparently did not consider that it needed justification. At most, they simply noted that the size of costs awards was within the power of the legislature. ${ }^{27}$ This is scarcely surprising. Costs had always been set by the legislature, and had always been set low. The practice was so deeply rooted that, when the legislature left some gap in the costs statutes, courts drew on other statutes to fill it. They would not invent a costs system of their own. ${ }^{28}$ In any event, courts and lawyers had little interest in justifying - or even in criticizing - a system which awarded the prevailing party an "attorney fee" of a few dollars. Their concern and their rhetoric ${ }^{29}$ were devoted to establishing the lawyer's right to collect larger fees from his own client.

The low level of costs, moreover, at first must have seemed less significant because of the possibility that a prevailing party could recover attorney fees from the loser as part of a damage award. Considering the inchoate state of the law of damages at this time, ${ }^{30}$ it is quite likely that juries took legal expenses into consideration when they assessed damages, as indeed is probably the case today. ${ }^{31}$ As

was equivalent to less than four dollars. Id. at 33, $56 \mathrm{n} .29$.) At about this time, Andrew Jackson also collected on occasion more than the statutory fee. Ely, The Legal Practice of Andrew Jackson, 38 TENN. HIST. Q. 421, 431-33 (1979). Daniel Webster likewise received (when he was lucky) fees from his clients larger than the statutory fee when he practiced in New Hampshire during the first decade of the nineteenth century. 1 The Papers of Daniel Webster, Legal Papers 246-49 (A. Konefsky \& A. King eds. 1982). On the other hand, so far as the author's imperfect efforts can show, during the 1780's John Marshall was following the Virginia legislature's fee scale-which clearly limited what lawyers could receive from their own clients. See $1761 \mathrm{Va}$. Acts, c. 8, $1778 \mathrm{Va}$. Acts, c. 14, and $1782 \mathrm{Va}$. Acts, c. 48, § 3, all in A Collection of all such PUblic ACts. . . As are now in force 84, 184 (Richmond 1785); 1 The PaPers of Jor:N Marshall 287-413 (H. Johnson ed. 1974).

25. Whipple v. Fuller, 11 Conn. 581, 585 (1836); Stevens \& Cagger v. Adams, 26 Wend. 451 , 459 (N.Y. 1841) (quoting Chancellor Kent's statement of 1828); Pangburn v. Bull, 1 Wend. 345 (N.Y. Sup. Ct. 1828) (argument of counsel); Foster v. Jack, 4 Watts 334, 339 (Pa. 1835); Newnan v. Washington, 8 Tenn. (Mart. \& Yer.) 79 (1827); see Potts v. Imlay, 4 N.J.L. 377, 379, 385 (1816) (Justices courts only); Duncan v. Breithaupt, 12 S.C.L. (1 McCord) 149 (1824).

26. J. Pitts, Eleven Numbers Against Lawyer Legislation and Fees at the Bar 5-7 (1843). Pitts did not support increased costs awards: a losing defendant "has atoned to the law for violating its sacred ties, in paying the cost of the suit . . ., and who has any right to demand any thing more?" Id. at 6 . His remedy was to simplify the law and forbid paid advocates-a return to the early colonial approach. Id. at $45-46$.

27. See, e.g., Arcambel v. Wiseman, 3 U.S. (3 Dall.) 306, 306 (1796); Potts v. Imlay, 4 N.J.L. 377,379 (1816).

28. Costs in Civil Cases, 30 F. Cas. 1058 (S.D.N.Y. 1852) (No. 18,284); cf. Hathaway v. Roach, 11 F. Cas. 818 (D. Mass. 1846) (No. 6213).

29. E.g., Lytle v. State, 17 Ark. 608 (1857); see Stevens \& Cagger v. Adams, 26 Wend. 451 (N.Y. 1841); Foster v. Jack, 4 Watts 334 (Pa. 1835); Duncan v. Breithaupt, 12 S.C.L. (1 McCord) 149 (1824); Newnan v. Washington, 8 Tenn. (Mart. \& Yer.) 79 (1827).

30. See J. Sayer, The Law of Damages (London 1770); Danzig, Hadley v. Baxendale: $A$ Study in the Industrialization of the Law, 4 J. LEGAL STUD. 249, 255 (1975); Horwitz, The Historical Foundations of Modem Contract Law, 87 HARv. L. REv. 917, 925-26 (1974).

31. H. BRACKenRIDGe, LaW Miscellanies 196 (Philadelphia 1814) (jury may include costs in damages, or leave them to the judge); $3 \mathrm{~W}$. BLACKSTONE, supra note 15, at 399; see O'Connell, $A$ Proposal to Abolish Defendants' Payment for Pain and Suffering in Return for Payment of Claimants' Attorneys' Fees, 1981 U. ILL. L. REv. 333. But see $1 \mathrm{M}$. BACON, supra note 15, at 525 (English jury required to tax costs separately from damages). Some states still allow juries to consider the plaintiff's legal expenses when they assess punitive damages. K. Redden, Punitive Damages 60 (1980). 
courts began to lay down rules to guide juries, there seemed to be a real possibility that legal expenses would be included in the measure of damages. ${ }^{32}$ As late as 1847, Theodore Sedgwick's treatise on damages found the cases conflicting and the correct rule hard to discern. ${ }^{33}$ Prevailing defendants could not, of course, recover legal expenses in the form of damages, but they might hope to recover them through a liberalized action for abuse of process. ${ }^{34}$

The reception of Arcambel v. Wiseman ${ }^{35}$ vividly demonstrates prevailing uncertainty about whether legal expenses could be recovered. This cryptic Supreme Court decision rejected a $\$ 1600$ allowance for attorney fees. The Court's per curiam opinion disposed of the fee in a single ambivalent sentence. "The general practice of the United States is in opposition to it; and even if that practice were not strictly correct in principle, it is entitled to the respect of the court, till it is changed, or modified, by statute." 36

Nowadays, Arcambel is cited as recognizing a general rule that attorney fees are not recoverable in the absence of legislation. ${ }^{37}$ Even had the Court approved the "principle" behind its "practice"-and it was not the last court to enforce the American rule without defending it-its decision might not have been influential, since at that time federal courts did not play a creative role but followed state costs practice. ${ }^{38}$ In any event, even in the federal courts Arcambel was at best a blinking beacon. Justice Story allowed the plaintiff in an 1813 patent case to introduce evidence of his legal expenses as damages, but then decided he was mistaken and granted a new trial on the authority of Arcambel. ${ }^{39}$ Only seven years later, he reversed himself again and allowed recovery, observing that other judges had not followed Arcambel, which he described as an admiralty case dealing with the recovery of costs but not damages. ${ }^{\mathbf{4 0}}$ Four years later, Story returned to the issue, declaring for the Supreme Court that "[i]t is the common course of the Admiralty, to allow expenses of this nature, either in the shape of damages, or as part of the costs." 11 After such vacillations, the law could not be described as clear.

32. E.g., St. Peter's Church v. Beach, 26 Conn. 355 (1857) (limited to punitive damages); Linsley v. Bushnell 15 Conn. 225 (1842); Rice v. Austin, 17 Mass. 197 (1821), overnuled, Barnard v. Poor, 38 Mass. (21 Pick.) 378 (1838); Wilt v. Vickers, 8 Watts 227 (1839), overnuled, Good v. Mylin, 8 Pa. 51 (1848).

33. T. Sedgwick, A Treatise on thi Measure of Damages 99-104 (1st ed. New York 1847).

34. Whipple v. Fuller, 11 Conn. 581 (1836); Pangburn v. Bull, 1 Wend. 345 (N.Y. 1828). Contra Potts v. Imlay, 4 N.J.L. 377 (1816). See generally Note, Groundless Litigation and the Malicious Prosecution Debate: A Historical Analysis, 88 YALE L.J. 1218 (1979).

35. 3 U.S. (3 Dall.) 306 (1796).

36. Id. at 306.

37. E.g., Alyeska Pipeline Serv. Co. v. Wilderness Society, 421 U.S. 240, 249-50 (1975). As Professor Goebel has explained, there was a federal statute regulating costs recovery, and Arcambel $v$. Wiseman was an effort to evade it. $1 \mathrm{~J}$. Goebel, History of THE Supreme Court of the United STATES 716 -18 (1971).

38. Costs in Civil Cases, 30 F. Cas. 1058 (S.D.N.Y. 1852) (No. 18,284); see The Baltimore, 75 U.S. 377 (1869).

39. Whittemore v. Cutter, 29 F. Cas. 1120 (C.C.D. Mass. 1813) (No. 17,600).

40. Boston Mfg. Co. v. Fiske, 3 F. Cas. 957 (C.C.D. Mass. 1820) (No. 1,681); see Whipple v. Cumberland Mfg. Co., 29 F. Cas. 934 (C.C.D. Me. 1843) (No. 17,516) (Story, J.) (flowing back river to obstruct plaintiff's mills, jury may consider plaintiff's legal expenses). Contra Stimpson v. Railroads, 23 F. Cas. 103 (C.C. 3d Cir. 1847) (No. 13,456) (Grier, J.).

41. The Appollon, 22 U.S. (9 Wheat.) 362, 379 (1824). Another Supreme Court Justice later stated (without mentioning Arcambel $v$. Wiseman) that the English statutes allowing the victor to recover full costs had been imported with the common law. Hathaway v. Roach, 11 F. Cas. 818 (D. Mass. 1846) (No. 6,213) 
What was clear was that courts were increasingly legitimating the right of lawyers to collect fees larger than anything recoverable under the costs statutes. Early decisions refused to allow trial lawyers to sue their client for fees greater than that provided in the costs statute, drawing on the English rule that barristers could not sue for their fees. ${ }^{42}$ To import this gentlemanly English tradition accorded with contemporary efforts to raise the status of the bar. ${ }^{43}$ It also grew out of the colonial system that limited lawyers' fees to the statutory amount. By the time of these decisions, however, that system was dead in practice, and court soon supplied a legal basis for the larger fees which lawyers were receiving. They upheld and enforced fee contracts between lawyers and clients. ${ }^{44}$ And they allowed lawyers to recover in quantum meruit ${ }^{45}$-an approach clearly implying that there was some standard for the assessment of fees found neither in the costs statute nor in the consent of the client.

These developments led directly to the legitimation of the contingent fee. Once freedom of contract between lawyers and clients was acknowledged, there was little ground for excepting contingent fee contracts. And once judges helped lawyers recover large fees from their clients, they could hardly refrain from allowing fee arrangements that would enable those who could not pay such fees in advance to get into court. Around the middle of the century, precedents disallowing contingent fees ${ }^{46}$ yielded to a more receptive view. ${ }^{47}$ As often, legitimacy followed reality; by this time, contingent fees were well established in practice, ${ }^{48}$ and many lawyers also performed the functions of collection agents. ${ }^{49}$

The American Rule thus emerged from a rough compromise. Lawyers gained the right to collect large fees from their clients, while restrictions on cost recovery remained as a symbolic vestige of the old regulatory approach. Why were the lawyers able to demolish the regulatory barriers? In part, the change occurred

(Woodbury, J.). But see Pacific Ins. Co. v. Conard, 18 F. Cas. 946 (C.C.E.D. Pa. 1830) (No. 10,647)

(Baldwin, J.) (limiting The Appollon to aggravated cases).

42. Law v. Ewell, 15 F. Cas. 14 (C.C.D.C. 1817) (No. 8,127); Mooney v. Lloyd, 5 Serg. \& Rawle 412 (Pa. 1819); Seeley v. Crane, 145 N.J.L. 35 (1835); cf. Scott v. Elmendorf, 12 Johns. 315 (N.Y. 1815).

43. See M. Bloomfield, American Lawyers in a Changing Society, 1776-1876, at 136-90 (1976).

44. Bayard v. McLane, 3 Del. (3 Harr.) 139, $217-22$ (1840); Stevens \& Cagger v. Adams, 23 Wend. 57 (N.Y. 1840), affd, 26 Wend. 451 (N.Y. 1841); see Badfish v. Fox, 23 Me. 94 (1843) (contract with reference to local usage).

45. Foster v. Jack, 4 Watts 334 (Pa. 1835); Newnan v. Washington, 8 Tenn. (Mart. \& Yer.) 79 (1827); Vilas v. Downer, 21 Vt. 419 (1849); see Robbins v. Harvey, 5 Conn. 335 (1824); Thurston v. Percival, 18 Mass. (1 Pick.) 415 (1823); Duncan v. Breithaupt, 12 S.C.L. (1 McCord) 149 (1824). The right to sue clients for fees may have been frequently exercised. A study of Boston litigation reports twenty-one such suits in 1880 for every 100 lawyers. R. Silverman, LAW' AND URBAN GroWTh 75 (1981).

46. Holloway v. Lowe, 7 Port. 488 (Ala. 1838); Thurston v. Percival, 18 Mass. (1 Pick.) 415 (1823); In re Bleakley, 5 Paige Ch. 311 (N.Y. Ch. 1835); see Rust v. Larve, 14 Ky. (4 Litt.) 411 (1823).

47. Ex parte Plitt, 19 F. Cas. 875 (C.C.E.D. Pa. 1853) (No. 11,228); Lytle v. State, 17 Ark. 608 (1857); Bayard v. McLane, 3 Del. (3 Harr.) 139 (1840); Newkirk v. Cone, 189 Ill. 449 (1857); Evans v. Bell, 36 Ky. (6 Dana) 479 (1838); Major's Exec. v. Gibson, 48 (Va. 1855).

48. See Bayard v. McLane, 3 Del. (3 Harr.) 139, 206, 212 (1840); 2 The Papers of Daniel Webster, Legal Papers 137-38 (A. Konefsky \& A. King eds. 1983); Foster v. Jack, 4 Watts 334, 338 (Pa. 1835). Some lawyers had introduced contingent fee devices well before this, perhaps to evade legislative fee regulations by acquiring part of the claim. AUSTIN, supra note 14, at 11, 29 reprinted in 13 AM. J. LEGAL HIST 244, 256-57, 271 (1969); see Ellis, supra note 10, at 143.

49. See M. Bloomfield, supra note 43 , at 277. 
because of factors unique to the legal profession: the growing political influence of lawyers, ${ }^{50}$ a possible decline in the intensity of antilawyer feeling, ${ }^{51}$ and the desire of businessmen to retain the best lawyers. ${ }^{52}$ But even without such factors, lawyer fee regulation could scarcely be expected to survive in a world built on the individual's freedom to conduct business without governmental restraint (and sometimes with governmental help).$^{53}$ Having established themselves as private businessmen, lawyers reaped the profits.

Why did lawyers not use their increasing power to push for a higher level of costs recovery? From the lawyer's point of view, such recovery is a mixed blessing. Courts and legislatures oversee the size of the award, and for every lawyer who extracts his fee from the defeated opposing party, there is another lawyer whose client complains of having to pay the lawyers on both sides. It seemed easier to collect from one's own client, or by contingent fee. At least this would be so at a time when most litigation concerned commerce or property and fees had not risen beyond the capacity of businessmen and property owners to pay. ${ }^{54}$ At this time, moreover, it was easy and cheap to become a lawyer or to enter other trades; an unsuccessful lawyer was more likely to move on or try something else than to organize the bar to press for costs reform. ${ }^{55}$ Beyond this, the same ideology of free contract and private business which lawyers used to liberate their fees from regulation conflicted with the propriety of high costs awards. This conflict was apparent in the important fee legislation of the mid-nineteenth century.

\section{IV}

\section{The American Rule is Recognized}

If the American rule had a heyday, it was during the second half of the nineteenth century. Though courts were reluctant or unable to explain why legislatures fixed the counsel fees that victorious litigants could recover at a nominal sum, they recognized that legislatures had in fact done so. They even extended the legislative policy by analogy. But as they did, both courts and legislatures began to chip away at the rule. The rule's significance also changed: from a byproduct of the freedom of lawyers to charge their clients what the market would bear, the rule showed signs of evolving into a barrier protecting corporate defendants from litigation.

In 1848, the Field Code of civil procedure reached the goal for which lawyers

50. See generally, G. Gawalt, supra note 24 ; see R. Ellis, supra note 10 , at 243-49.

51. See M. BlOOMfield, supra note 43, at 32-58. But see J. PITTs, supra note 26, for some lurid antilawyer rhetoric.

52. See M. Horwitz, The Transformation of American LaW, 1780-1860, at 140-41 (1977); 1 R. Swaine, The Cravath Firm and Its Predecessors 14-16 (1946); 1 C. Fuess, Daniel Webster 209-10, 64 (1930). Obviously, this was not a wholly new development; rich people had always been able to obtain able lawyers.

53. See O. HandLIN \& M. HaNdLin, supra note 12 , at 51-75; M. HEATH, supra note 12 , at 357.67 ; L. Hartz, Economic Policy and Democratic Thought: Pennsylvania, 1776-1860, at 254-62 (1948); J Primi, Economic Policy in the Development of a Western State, Missouri, 1820-1860, at 1-17 (1954).

54. See 2 A.-H. Chroust, supra note 7, at 87-90, 108-11 (1965).

55. See L. FRIEDMAN, supra note 10, at 266-69, 275-78. 
had been striving during the previous decades. In decisive language, the Code struck down all provisions "establishing or regulating the costs or fees of at torneys" and declared that "hereafter the measure of such compensation shall be left to the agreement, express or implied, of the parties."56 The Code went on to allow recovery of nominal attorney fees as costs: twenty dollars, for instance, was the usual recovery for a trial of both fact and law, although in difficult or extraordinary cases the court could allow a fee of up to $10 \%$ of any recovery up to $\$ 500$ and $5 \%$ of any excess. ${ }^{57}$ Although some clients were paying fees at this level for some cases, elite lawyers charged far more. ${ }^{58}$

Like the Code itself, its exegesis by David Dudley Field and his fellow Commissioners emphasized lawyers' freedom to contract with their clients for fees.

We cannot perceive the right of the state, to interfere between citizens, and fix the compensation which one of them shall receive from the other, for his skill or labor. . . . It has no more just right to do this, than it has to fix the price of property. . . . If it be said, that the attorney is an officer, admitted by the courts, and therefore, in a position different from the others, we answer, that he is not a public officer, chosen to perform public duties. He is admitted to practice in the courts, for private purposes, and on behalf of private persons. $\mathrm{He}$ is, in every respect, a private agent. . . . Freedom of industry is one of the strongest demands of the time. ... .

One case requires little thought; and almost takes care of itself; another requires a vast amount of study, careful preparation, and great learning. These cannot be measured by any table of fees.

The only just rule on the subject, in respect to the lawyer, is the same, as in respect to every professional person; that is, to enforce the contracts made by him. Let him make his engagement with his client, as they can agree between themselves, or if there be no express agreement, let the rate of compensation be determined by the usage in such cases. ${ }^{59}$

Of course these were familiar Victorian arguments for the then dominant laissez-faire ideology ${ }^{60}$ It was appropriate that they came from Field, later a prominent devotee of profit-seeking initiative. ${ }^{61}$ Field's words also demonstrate that the line between "public" governmental activity and "private" behavior had become firm enough to shield lawyers from irksome duties to the state. ${ }^{62}$ At the

56. 1848 N.Y. Laws 258. At almost the same time as the Code was passed, Virginia likewise ended its long history of fee regulation. $4 \mathrm{~J}$. MinOR, Institutes of COMMON and StaTUTE LAW 200-04, 213-14 (3d ed. 1893).

57. 1848 N.Y. Laws 262,263 . These fees were larger than those previously recoverable, which for instance allowed a counsellor only five dollars for a trial. 1840 N.Y. Laws 2. But this comparison overstates the difference: the 1840 statute allowed relatively small sums for each of a relatively large number of services, while the Field Code lumped costs awards into fewer but larger items

58. R. Swaine, supra note 52, at 103, 164; T. Sedcwick, How Shall THE LaWyers Be Paid? 9 (New York 1840); see S. Brown, The Life of Rufus Choate 432 (1898); J. Frank, Lincoln as a LaWyer 3940 (1961); 2 The Papers of Daniel Webster, Legal Papers 173 (A. Konefsky \& A. King eds. 1983).

59. First Report of the Commissioners on Practice and Pleading, Code of Procedure 204-06 (1848) [hereinafter cited as First Report].

60. P. Atiyah, The Rise and Fall of Freedom of Contract 256-505 (1979); Gordley, Equality in Exchange, 69 Calif. L. REv. 1587, 1592-1603 (1981); see O. Handlin \& M. Handlin, supra note 12, at 5153, 243; L. HARTZ, supra note 53, at 79-81.

61. Field's son wrote in 1870 , while defending his and his father's representation of James Fisk and Jay Gould, that "we endeavor to get fees proportionate to the labor in each case, and if our clients do not complain, I do not perceive who else can ... . Last year and the year before, his sworn returns to the internal revenue assessor were about $\$ 75,000$." Correspondence reprinted in A. KAUFMAN, PROBLEMS IN Professional Responsibility 249, 252 (1976); see Schudson, Public, Private and Professional Lives: The Correspondence of David Dudley Field and Samuel Bowles, 21 AM. J. LEGAL Hist. 191 (1977).

62. See supra text accompanying note 21. Field's brother, Justice Stephen J. Ficld, was a leading 
same time, court clerks were becoming sufficiently "public" to warrant a move toward limiting the fees they could exact from litigants ${ }^{63}$-a move which caused an opponent of the corresponding federal costs bill to describe it as one "for transferring fees and costs from clerks and marshals to attorneys." 64

After freedom of contract had been proclaimed, was there room to include realistic attorney fee awards in court costs? There need be no discrepancy between free contract and realistic costs awards. Awards can be justified as promoting efficiency by internalizing the costs of litigation and their amount can be based on the market value of legal services. ${ }^{65}$ After all, the Code Commissioners themselves approved resort to "usage" to fix the fees owed by a client to his lawyer in the absence of a contract. But market value fee awards would have been a radical break with tradition, and perhaps with legislative realities. More basically, the Commissioners' free market position was not based on efficiency. They considered it illegitimate for the government to impose a contract on a client and his lawyerbut if this were so, how could one justify forcing a client to pay for someone else's lawyer? They thought that no one was as able as the lawyer and client were to appraise the just value of the lawyer's services-but if this were so, how could a court or legislature fix the amount of just fee award?

Perhaps for these reasons, David Dudley Field and his fellow Commissioners performed the intellectual equivalent of the compromise that had already emerged, under which lawyers could charge their client what the market would bear, while legislatures were left to display an insignificant frugality by keeping down costs awards. The Commissioners started boldly enough:

The losing party, ought however, as a general rule, to pay the expense of the litigation. He has caused a loss to his adversary unjustly, and should indemnify him for it. The debtor who refuses to pay, ought to make the creditor whole.

Then how shall the amount of indemnity be regulated? It cannot be adjusted with precision, from the nature of the case, but we can get an approximation to it. There are two modes; one by letting the court or the jury fix it, in each particular case, according to its circumstances; the other by giving certain allowances, graduated in part by the necessary labor performed, and in part by the amount in controversy. The latter strikes us as preferable, because it leaves nothing to arbitrary discretion. ${ }^{66}$

This rejection of case by case evaluation was inconsistent with the Commissioner's explanation that the labor bestowed on a suit "cannot be'measured by any table of fees." 67 Perhaps the Comissioners feared that discretionary awards would lead to judicial favoritism. ${ }^{68}$ But worse was to come: at this crucial point in their analysis, the Commissioners abruptly abandoned their task. "We have not designated the

proponent of the distinction. McCurdy, Justice Field and the Jurisprudence of Covermment-Business Relations: Some Parameters of Laissez-Faire Constitutionalism, 1863-1897, 61 J. AM. HisT. 970 (1975).

63. Compare 1848 N.Y. Laws 267 with 1840 N.Y. Laws 5; see In re Clerk of Albany County, 3 Code Rep. 102, 5 How. Pr. 11 (Alb. Gen. T. 1850).

64. 26 Cong. Globe, 32d Cong., 2d Sess. 584 (1853)(Sen. Adams), discussing Act of Feb. 26, 1853, $\S \S 1,3,10$ Stat. 161 ; see infra text accompanying note 87.

65. See R. POSNER, ECONOMIC ANalysis OF LAW 447-53 (2d ed. 1977); Berger, Court Awarded Attorney's Fees: What is "Reasonable"?, 126 U. PA. L. REV. 281 (1977).

66. First Report, supra note 59, at 206-07.

67. See id. at 206; see also supra text accompanying note 59.

68. Long afterwards, Field asserted that "experience" proved the desirability of limiting recoverable costs to the fees of court officers, apparently because of the danger of oppressive awards and uncontrolled 
sums to be inserted in the act," they said, "preferring that it should be done by the legislature." And the accompanying draft Code contained blanks where the legislature was to fill in the size of the fee award in dollars or percentage of the recovery. ${ }^{69}$ The Commissioners gave no reason for this omission, and no guidance as to how the legislature should fix fees-except to observe that whatever was provided would sometimes be too much, and sometimes too little. ${ }^{70}$ The legislature took the opportunity to insert the low figures already mentioned.

At the core of the history of the American rule, then, we find a void. Although the report accompanying the Field Code gave a lengthy explanation of the costs provisions, it stated no reason for denying prevailing parties a realistic attorney fee as part of the costs. On the contrary, it argued in favor of a fee award, only to duck out when it came to fixing the amount of the award or authorizing courts to fix it. One can only speculate about why this happened. On the intellectual level, the arguments Field advanced to support freedom of contract for lawyers and clients undercut those needed to support adequate fee awards. On the political level, the lawyers were out to legitimize large fees paid to them by their clients, and were willing to let the legislature keep costs awards down because they did not rely on them for their own payment. But neither explanation appears in the contemporary documentation.

Contemporary evidence supports the view that the Field Commission's incoherence reflects compromise between the bar and its critics, and perhaps within the bar as well. Only three years before the Field Code was passed, a petition to the New York legislature sought regulation limiting lawyers' pay "to a just standard with that paid for indispensable, productive labor." have been mollified by the resulting 1845 legislative committee report, with its panegyrics to "the great principles of supply and demand" and the value of lawyers as "warning beacons to the masses of the human family, preventing their shipwreck upon the breakers of political power."72 Like the Field Commission report, this report approved in theory the shifting of at least some legal expenses to losing parties, but shied away from specifying how much. Theodore Sedgwick, III, a personal and professional associate of David Dudley Field and a student of the law of damages, ${ }^{73}$ was bolder. He agreed with Field and the 1845 legislative committee that lawyers should be as free as "the clergyman, the physician, the sculptor, the tailor" to contract with their clients for whatever fee the parties found appropriate. ${ }^{74}$ But he went beyond them to propose that winners recover from

judges. First Report to the A.B.A. (1885), reprinted in 3 D. Field, SpeEches, Arguments, ANd MiscellaNEOUS PAPERS 177-78 (1890).

69. First Report, supra note 59, at 207, 209-10.

70. Id. at 207.

71. Report of the Select Committee on Lawyer's Fees and Costs in Courts of Law (Apr. 15, 1845), in 6 Docs. Of The Assembly of the State of N.Y., 68th Sess., No. 227, at 1 (1845).

72. Id. at 1,2. At least one beacon cast little light: one lawyer predicted that the Field Code would bankrupt the bar, apparently because no one would want to sue under its reformed procedure. 1THE Diary of George Templeton Strong 324, 328 (A. Nevins \& M. Thomas eds. 1952).

73. See A. Schlesinger, The Age of Jackson 332 (1945); T. Sedgwick, supra note 33, at 99-104.

74. T. SEDGwick, supra note 58 , at $3,4-5,7$. This pamphlet was published anonymously, but library cataloguers attribute it to Sedgwick. 
losers substantial costs awards, calculated as a percentage of the sum in dispute, with an extra charge meant to discourage delay and based on the duration of the suit. ${ }^{75}$ Sedgwick insisted that lawyers' pay must be high: "The science which regulates all the business relations of mankind, must forever be a toilsome, an honorable and an expensive science." 76 He denounced legislation providing for low costs recovery as a blow to the security of property bearing "the strongest impression of the power of the debtor interest" and called on legislators to resist the "poisonous spirit of party" and stand up for the true interests of the public and the bar. ${ }^{77}$ But the New York legislators were not persuaded.

Controversy over the proper level of costs recovery followed the Field Code from New York to the other states. At least for a time, California adopted a scheme like Sedgwick's, entitling a prevailing party to recover five percent of the first thousand dollars recovered or claimed, and two percent of the surplus. ${ }^{78}$ At the time, this must have been a reasonably typical fee for routine collection work in the Western states. ${ }^{79}$ Other states, however, provided for only nominal costs awards. ${ }^{80}$ Still others may have found the matter too hot to handle, and passed the Code without any costs provisions, ${ }^{81}$ or with provisions providing for costs awards, but not specifying their amount or ingredients. ${ }^{82}$ But in one respect Field's scheme was not altered. Nowhere, so far as the author has been able to determine, did the legislature write into the Code provisions regulating what lawyers could charge their own clients.

Congress adopted the Field compromise in 1853 when it passed the costs statute still substantially in effect today, ${ }^{83}$ replacing the former practice under which each federal court followed the costs rules in the state where it sat. ${ }^{84}$ Like the Field Code, the federal statute protected the right of lawyers to charge and receive from their clients "such reasonable compensation for their services, in addition to the taxable costs, as may be in accordance with general usage in their

75. Id. at 11-16. For a claim between $\$ 500$ and $\$ 1,000$, for instance, the winner would recover $8 \%$ of the judgment (or $8 \%$ of the sum claimed, if the defendant prevailed) plus $1 / 2 \%$ of the same amount per month of litigation.

76. Id. at 11 .

77. Id. at 23, 24-26. Sedgwick's rhetoric may have been heated by the "antirent" agitation then underway in New York. See D. Ellis, Landlords and Farmers in THE Hudson-MoHawk Region, 1790-1850, at 225-312 (1946); see also L. Benson, The Concept OF JACKSONIAN DeMOCRACY 35, 43-46 (1961) (1831 abolition of imprisonment for debt); 2 D. Alexander, A Political History Of the State OF NEW YORK 109-112 (1906) (1846 popular election of judges).

78. $1851 \mathrm{Cal}$. Stat. 502. The 1872 revision of the Code eliminated this provision. The revision allowed costs, but did not state what sums or items were included. CAL. Civ. Proc. CoDE $\$ \S 1021-39$ (1872).

79. See M. BLOOMfield, supra note 43, at 277. But higher percentages were sometimes charged. Id. at 278; Bloomfield, The Texas Bar in the Nineteenth Century, 32 VAND. L. REV. 261, $270-72$ (1979).

80. E.g. Act of Apr. 28, 1854, 1854 Wash. Laws 201-04; Iowa Laws 1860, c. 30 (amending Code to reduce $\$ 5$ attorney fee award to zero). Some non-Code states also abolished all attorney fees awards. 1839 Miss. Laws, c. 33; H. R. Exec. Doc. No. 93, 32d Cong., 1st Sess. 18-26 (1852).

81. Act of Feb. 24, 1849, 1849 Mo. Laws 73.

82. E.g., Kansas Acts 1859, c. 25, $\S \S 1,563,565$; see Swartzell v. Rogers, 3 Kan. 375 (1866) ("costs and expenses" does not include an attorney's fee).

83. Act of Feb. 26, 1853, 10 Stat. 161 (1964) (current version at 28 U.S.C. $\S \S 1920-24$ (1976)).

84. See Cases cited supra note 38 . 
respective States, or may be agreed upon between the parties."85 But the fees recoverable as costs were fixed at tiny amounts, which did not exceed $\$ 20$ unless there was an appeal. ${ }^{86}$

Congressional discussion of this statute reveals some of the same paradoxes found in the history of the Field Code. Congress's main concern seems to have been that some clerks, marshalls, and district attorneys were reaping excessive rewards under a system that incorporated state costs provisions. ${ }^{87}$ There was some discussion of the undesirable size of costs awards and their variation from state to state, and some consideration of whether lawyers who received fee awards as part of the costs would charge their own clients less. ${ }^{88}$ But no supporters of the bill tried to justify the low level of fees. It was an opponent of the bill, who wished to deny inclusion of any fee recovery in the costs, who challenged the justification of such recovery on individualistic grounds: "What propriety can there be in requiring the unsuccessful [criminal] defendant to pay for the attorney who prosecutes him? Men often differ honestly in regard to their rights, and it is a very difficult matter to determine which is wrong." 89 Senator Bayard responded for the bill's supporters with an explanation of the need for uniformity among the various federal courts, and a lukewarm assertion that "a certain amount, at all events, is allowed to the party succeeding." 90 As with the Field Code, those who established the American rule in the federal courts gave no reasons for it, and if anything purported to support a contrary rule.

Congress had no need to justify low recovery, since in most instances the attorney fees recoverable under the federal bill were actually larger than the sums previously allowed in federal courts under state costs legislation. By this time, nine states allowed no recovery of attorney fees in civil suits, while most of the rest allowed only minuscule amounts. ${ }^{91}$ The federal statute thus did not establish the American rule but modified it slightly and made it uniform for all federal courts. Congress was not reducing costs recovery for legal expenses but increasing it. Even this was something of a byproduct of the regulation of the fees of clerks, marshalls, and U.S. attorneys.

Despite this equivocal heritage, courts gave the American rule a warm reception during the second half of the nineteenth century. Of course, they followed the

85. Act of Feb. 26, 1853, 10 Stat. 161 (1964).

86. Id.

87. Cong. Globe, 32d Cong., 2d Sess. App. 207 (1853); H.R. ReP. No. 50, 32d Cong., 1st Sess. 1-3 (1852). Congress had long been concerned about this problem. Act of March 3, 1841, 5 Stat. 419, 427-28; Act of May 18, 1842, 5 Stat. 474, 483-84; H.R. Doc. No. 122, 27th Cong., 3d [sic] Sess. (1843).

88. Cong. Globe, 32d Cong., 2d Sess. 585(1853); see H.R. ReP. No. 50, 32d Cong., 1st Sess. 1-6 (1852); Act of August 23, 1842, 5 Stat. 516, 518 (authorizing Supreme Court to regulate taxation of attorney, clerk, and marshall costs by rule "for the purpose of further diminishing the costs and expenses"; the Court did not use this authority).

89. Cong. Globe, 32d Cong., 2d Sess. 584 (1853). Senator Adams of Mississippi, who made these comments, was seeking to continue his own state's practice, which denied any fee recovery, in the federal courts sitting in his state.

90. Id. Senator Bayard could not be expected to favor limiting an attorney's pay to what could be recovered from an opposing party; his father, also a senator, had helped legitimate contingent fees in Delaware. See Bayard v. McLane, 3 Del. (3 Harr.) 139 (1840).

91. H. Exec. Doc. No. 93, 32d Cong., 1st Sess. 18-26 (1852); see Day v. Woodworth, 54 U.S. (13 How.) 363 (1851). 
statutory limits on costs recovery; that had always been the case. But courts read the statutes so as to avoid recovery of attorney fees as costs. ${ }^{92}$ Courts also relied on the legislative policy behind the costs statutes (without saying what that policy was) as a ground for denying recovery of attorney fees in the form of damages. ${ }^{93}$ Some judges used the same policy to strike down contractual clauses requiring one party to pay the other's legal expenses if the latter had to sue to enforce the contract. ${ }^{94}$ And some judges even held statutes authorizing certain parties to recover their actual legal expenses to be unconstitutional, finding them to violate the equal protection or due process clause. ${ }^{95}$ This last group of cases will be discussed later.

Willingness to apply the American rule was not matched by a willingness to justify it. Courts were content to refer generally to the legislative policy without specifying any reasons for it. One might think that this was because there were no reasons to give, but, curiously enough, courts were quite active in stating or inventing reasons for the rule that attorney fees could not be recovered as damages. Some of these reasons-that the objective value of attorney services is hard to determine, ${ }^{96}$ and that the extent of a party's legal expenses reflects his own decisions about how to litigate, for which the other party should not be liable ${ }^{97}$ — seem equally applicable to the American rule. Indeed, these reasons embody the same principles of individualism and freedom of contract that underlie the Field Code. Perhaps the vociferous defense of the denial of attorney fees as damages can be traced to two other factors. Since damage rules were judge-made, some judicial justification for them was required. And to allow fees as damages would have benefited prevailing plaintiffs but not prevailing defendants-a prospect judges and scholars regarded with disapproval. ${ }^{98}$

Even if no reasons were given, recognizing the principle that substantial attorney fees could not be recovered as costs, and extending the principle by analogy, fits into a familiar pattern of late nineteenth century formalism. ${ }^{99}$ Judges

92. E.g., Hoffman v. Smith, 61 Miss. 544 (1884); Swartzell v. Rogers, 3 Kan. 375 (1866)

93. E.g., Oelrichs v. Spain, 82 U.S. (15 Wall.) 211, 230-31 (1872); Hoffman v. Smith, 61 Miss 544 (1884).

94. E.g., Bullock v. Taylor, 39 Mich. 137, 140 (1878) (Cooley, J.). But see Merchants' Nat'l Bank v. Sevier, 14 F. 662, 667 (1882).

95. E.g, Gulf, C. \& S.F. Ry. v. Ellis, 165 U.S. 150, 154-55 (1897) (citing cases); see Annot., 11 A.L.R. $884(1921)$.

96. Oelrichs v. Spain, 82 U.S. (15 Wall.) 211, 230-31 (1872); Reggio v. Braggioti, 61 Mass. (7 Cush.) 166, 170 (1851) (Shaw, C.J.).

97. E.g., St. Peter's Church v. Beach, 26 Conn. 355 (1857); A. Sedgwick, Elements of DamaGes 38 (1896). The same point seems to lie behind assertions that an opposing party's legal expenses are too remote or unforeseeable to be recovered. See Stewart v. Sonneborn, 98 U.S. 187, 197 (1878); Good v. Mylin, $8 \mathrm{~Pa}$. 51 (1848) (Gibson, C.J.).

98. See Oelrichs v. Spain, 82 U.¿. (15 Wall.) 211, 230 (1872); St. Peter's Church v. Beach, 62 Conn. 355 (1857); A. SEDGWICK, supra note 95, at 37-38. Another theory-that judges distrusted fee awards as damages because they would be assessed by juries rather than judges-is hard to reconcile with the established practice of having jury trials for lawyers' fee suits against clients. E. THORNTON, A TREATISE ON Attorneys at LaW 960-61 (1914); see McAllister's Appeal, 59 Pa. 204 (1868) (Sharswood, J.).

99. See generally G. White, TORT LAW in America 31 -56 (1980); G. Gilmore, The Death OF ConTRACT $12-17$ (1974); Gordon, Holmes' Common Law as Legal and Social Science, 10 HOFSTRA L. REV. $719,727-$ 28 (1982); Kennedy, Toward an Historical Understanding of Legal Consciounness: The Case of Classical Legal Thought in America, 1850-1940, 3 RESEARCH IN LAW AND SOC. 3 (1980). See M. HORWITZ, supra note 52, at 253-66. But see Schwartz, Tort Law and the Economy in Nineteenth-Century America: A Reinterpretation, 90 YALE L.J. 1717 (1981). 
and lawyers of this period sought clear, logically consistent rules which would make it possible for people and corporations-in this case prospective litigants-to plot their actions with precise information about whether and how the government might impinge on them. And those rules tended to restrict liability and leave losses - in this case, litigation expenses-where they fell, strengthening the position of those already rich and powerful. Shifting the expenses of one litigant to another was regarded as something of a confiscatory act, to be avoided unless the legislature unequivocally required it. ${ }^{100}$ Indeed, by the end of the century procedural thinkers claimed to regard litigation in general as an evil to be discouraged. ${ }^{101}$

Perhaps the most important exception to the American rule to develop during this period, if importance is measured by frequency of use, was fully consistent with these principles. This was the recovery of attorney fees pursuant to a clause of the contract under which the plaintiff sued. No principles of individualism, formalism, or laissez-faire barred the enforcement of a fee clause to which the parties had agreed. The courts, albeit with some hesitation, upheld such clauses. ${ }^{102}$ Lenders and landlords could easily write fee clauses protecting themselves into their standardized contracts. Courts also implied fee clauses in contracts obviously intended to shield the parties from the costs of litigation. ${ }^{103}$ Some courts even used the contract rationale to allow wrongly enjoined defendants to recover on an injunction bond for the legal expenses of getting the injunction dissolved. ${ }^{104}$

The contract rationale likewise furnished at least some support for recovery of attorney fees under the common fund theory, which also dates from this period. ${ }^{105}$ Under that theory, a party who had created or preserved a fund was entitled to recoup part of the legal expenses of doing so from the fund's beneficiaries by paying his lawyer out of the fund. "He has worked for them as well as for himself." 106 Fee recovery is thus a mere payment for services rendered, which in no way offends the principles of individualism or laissez-faire. It is, the argument runs, like recovery of customary fees by a lawyer from his own client, not like recovery from an opposing party. ${ }^{107}$

Of course, this is not the whole story. One contemporary critic of the common fund theory observed: "No man can be forced against his will into the position and liabilities of a client; nor can the role of a free-booter, levying a tax upon all who seek their rights in a suit as upon his legitimate clientage, be regarded a repu-

100. See Hoffman v. Smith, 61 Miss. 544, 547-48 (1884) (fee award statute construed narrowly: when there is genuine dispute, litigant should not be required to pay adversary's counsel).

101. R. Silverman, supra note 45, at 78-80 (1981); see authorities cited, infra note 135.

102. E.g., Tallman v. Truesdell, 3 Wis. 393, 403 (1854); Merchants' Nat'l Bank v. Sevier, 14 F. 662 , 667 (1882).

103. Ryerson v. Chapman, 66 Me. 557 (1877) (warranty of title); Pond v. Harris, 113 Mass. 114 (1873) (arbitration contract).

104. E.g., Cook v. Chapman, 41 N.J. Eq. 152, 2 A. 286 (1886). Contra Oelrichs v. Spain, 82 U.S. (15 Wall.) $211,223-24$ (1872).

105. See Trustees v. Greenough, 105 U.S. 527,533 (1881).

106. Id. at 532.

107. See id. at 535 . 
table one for a lawyer to play." 108 As Professor Dawson's magisterial articles have shown, the common fund doctrine rests ultimately on the belief that courts should assist certain kinds of litigation believed to confer widespread benefits. ${ }^{109}$ Perhaps the hidden hand of policy was already at work in the Greenough case, which first recognized the common fund doctrine. Comments in that decision suggest that the majority was concerned to legitimate fee awards in railroad receiverships, which were then a new and controversial federal court specialty. ${ }^{10}$ The Court also showed itself more willing to encourage lawyers than clients to sue. ${ }^{111}$

While courts were allowing fee recovery on the basis of real or fictitious contracts, legislatures began to launch more direct attacks against the American rule. Three federal statutes, the voting rights legislation of 1870, the Interstate Commerce Act of 1887, and the Sherman Act of 1890, allowed successful plaintiffs to recover their legal expenses in addition to liquidated damages, ordinary damages, or a treble damage award, ${ }^{112}$ A host of state statutes likewise allowed fee recovery. The first group of these was passed during the Granger Era ${ }^{13}$ and required railroads to pay fees when found liable for charging unlawful rates ${ }^{114}$ or harming livestock. ${ }^{115}$

Significantly, these statutes were usually one-way: the successful plaintiff recovered a realistic fee, but the successful defendant did not. Legislatures of this period were beginning to look at realistic attorney fee awards less as bounties for greedy lawyers and more as aids to needy plaintiffs or sanctions against corporate defendants. ${ }^{116}$ Populist legislative attitudes toward fee awards may have changed as the typical suit ceased to be a businessman's action to recover a debt and

108. Guy, Allowances by Courts of Fees to Counsel, 13 VA. L.J. 533, 544 (1889) (emphasis in original). This author attributed the spread of fee awards in Virginia to carpetbaggers and the federal courts.

109. Dawson, Lawyers and Involuntary Clients: Attomey Fees from Funds, 87 HARV. L. REV. 1597 (1974); Dawson, Lawyers and Involuntary Clients in Public Interest Litigation, 88 HaRV. L. REV. 849 (1975); see Dawson, The Self-Serving Intermeddler, 87 HARV. L. REV. 1409 (1974).

110. See Trustees v. Greenough, 105 U.S. 527, 536 (1881); id. at 538 (Miller, J., dissenting). On the rise of the railroad receivership, see C. Fairman, MR. JUSTICE Miller AND THE Supreme Court, 186290 , at $237-49$ (1939).

111. Compare Trustees v. Greenough, 105 U.S. 527, 538 (1881) (Miller, J., dissenting) (to allow common fund plaintiffs to recover the value of their own time would create overincentive) with Central R.R. \& Banking Co. v. Pettus, 113 U.S. 116 (1885) (plaintiff's lawyer may recover common fund fee larger than what plaintiff agreed to pay him).

112. Act of May 31, 1870, 16 Stat. 140, $\S \S 2,3$, repealed by Act of February 8, 1894, 28 Stat. 36; Act of February 4, 1887, 24 Stat. 379, $\$$; Sherman Antitrust Act $\$ 7,26$ Stat. 210 (1890).

113. The Grangers were fraternal organizations of farmers that became powerful during the agrarian discontent of the early 1870's. They attempted, among other things, to regulate railways and grain elevators. See S. Buck, The Granger Movement (1913).

114. Act of May 2, 1873, 1873 Ill. Pub. Laws 135, 138; 1874 Minn. Gen. Laws, c. 26, § 15. Similar provisions later appeared elsewhere, and probably influenced the Interstate Commerce Act's fee provision cited supra note 112. See Report of the Senate Select Commission on Interstate Commerce, S. REP. NO. 46, 49th Cong., 1st Sess. 72, 93, 95, 100-01, 103, 107, 127 (1886).

115. E.g., 1874 Kan. Sess. Laws, ch. 94; 1875 Minn. Laws, ch. 98, § 5. For a precursor also directed against railroads, see $1866 \mathrm{~Pa}$. Laws, ch. 106 (railroad or other corporation liable for fees when bondholder must sue to collect interest on bond previously held valid). Later statutes provided for attorney fees in suits against insurance companies and to enforce workmen's liens. See Annot., 11 A.L.R. 884 (1921).

116. Compare Cong. Globe, 41 st Cong., 2d Sess. App. 469 (1870) (Sen. Casserly, unsuccessfully opposing liquidated damages and attorney fee awards to those denied right to vote as breeding "professional vermin") with 21 CoNG. Rec. 1768, 2569, 1571, 3146 (1980) (Sherman Act: concern that litigation expenses would deter private suits); Compare 1889 Ill. Laws, p. 362 (fees in suit for unpaid wages) with 
became a tort suit against a corporation. ${ }^{117}$ The same shift made itself felt in the bar, as Judge Cooley and corporate lawyers criticized the contingent fee as encouraging negligence suits against corporations, while others praised it as equalizing plaintiffs and corporate defendants. ${ }^{118}$ In any event, just as courts were taking up and extending the legislative policy against full fee recovery, legislatures began to abandon it.

The resulting clash is clearly visible in Gulf, Colorado $\mathcal{E}$ San Francisco Railway $v$. Ellis, one of the numerous cases in which courts invalidated fee statutes as unconstitutional. ${ }^{119}$ Ellis reached the Supreme Court in 1896, when conservatives were relying on the courts as never before to protect corporations and property rights from the majority. ${ }^{120}$ Six Justices condemned an innocuous Texas statute which authorized a ten dollar attorney fee to a plaintiff establishing a claim no larger than fifty dollars against a railroad for injury to livestock, unpaid wages, overcharges, or other damages. The plaintiff Ellis had recovered fifty dollars after the defendant's train ran down his colt. Since Ellis's lawyer did not bother to defend his ten dollar fee award by appearing before the Supreme Court, a balanced discussion could perhaps not have been expected. Nevertheless, the fervor with which Justice Brewer filled his opinion is striking. He depicted the plight of oppressed railroad corporations, which unlike other defendants were punished when they lost, yet unable to recover when they won. The amount of the fee might be small, but if upheld it could lead to larger exactions. Corporations had the same right to equal protection as human beings, and could not be singled out by arbitrary classifications. The statute was too broad to be justified as a deterrent to livestock injuries, and too narrow to be upheld as ensuring payment of small debts. With a quotation from the Declaration of Independence, and a lengthy description of the case law, Justice Brewer dispatched the ten dollar fee, over the dissent of Justices Gray, Fuller, and White.

Such a decision, and such an opinion, might suggest that the American rule, which first saw the light as a concomitant of the lawyer's freedom to contract for his own fees, had now been transformed into a bulwark for tortious corporations. Such ideological transformations were common as society moved from individualism to corporate capitalism. ${ }^{121}$ And the Ellis court was not alone in treating a fee award as a punishment, justifiable only when the defendant had committed some illegal act. ${ }^{122}$

Atchison, T. \& S.F. R.R. v. Matthews, 174 U.S. 96 (1899) (award of fees in fire damages suit encourages defendant railroad to prevent fires).

117. See R. Silverman, supra note 45, at 17, 20; see M. Hindus, The Files of The MassachusetTs SuPERIOR COURT, 1859-1959, at 137 (1979); Friedman \& Percival, A Tale of Two Courts: Litigation in Alameda and San Benito Counties, 10 LAW \& Soc'y REV. 267, 280-83 (1966). The first two of these sources are limited to litigation in the Boston area.

118. E. Countryman, The Ethics of Compensation for Professional Services 23-47 (1882).

119. 165 U.S. 150 (1897). For other such cases, see id. at 160-63; Annot., 11 A.L.R. 884 (1921).

120. See A. Paul, Conservative Crisis and the Rule of Law (1960).

121. See, e.g., S. Fine, Laissez Faire and The General-Welfare State 96-164 (1956).

122. E.g., Dow v. Beidelman, 49 Ark. 455, 5 S.W. 718 (1887) (upholding statute as penalty for railroad tort). But see Wilder v. Chicago \& W.M. Ry., 70 Mich. 382, 38 N.W. 289 (1888) (invalidating statute as penalty for defending case). The earliest fee statute the author has found (1855 Mass. Acts, ch. 215, 
Yet there is another side to the coin. Although the Ellis decision repeatedly called the attorney fee award a punishment, it nowhere tried to justify the American rule or write it into the Constitution. On the contrary, Justice Brewer said that "there might be no impropriety in giving to every successful suitor attorney's fees." 123 He clearly implied that fees might also be awarded against railroads as a sanction for violating safety regulations or against defendants who failed to pay wage claims or small debts. ${ }^{124}$ The majority thus viewed the case as turning on discrimination against railroads, not on the inequity of fee awards. In later casesalbeit over the resistance of Justices Brown, Peckham, McKenna, and Harlanthe Court upheld many fee statutes ${ }^{125}$ and struck down only one. ${ }^{126}$

In the long run, the passage of a fee statute by Texas proved to be more important than its invalidation by the Supreme Court. As the circumstances of the Ellis case showed-the railroad litigated a ten dollar fee in five different Texas courts, ${ }^{127}$ and then in Washington, where Ellis and his lawyer could not present their side of the case-the equality of parties which the Court sought to invoke had become an illusion. As people began to think of the paradigmatic civil case as one brought by an injured human being against an institutional litigant, the pressure for reforms easing a plaintiff's access to court began to gather. ${ }^{128}$ And as voters and legislatures found it necessary to regulate railroads and other businesses, they would have to create procedural means to implement their regulations, whether through governmental litigation, administrative agencies, or attorney fee awards. So it is not surprising that Texas reenacted the statute struck down in Ellis in broader form, and that the Supreme Court upheld it. ${ }^{129}$

\section{V \\ The American Rule is Explained}

The twentieth century brought with it increased interest in the American rule and attempts to explain it, leading eventually to its decline (though not its repeal). It was in this period that commentators first bestowed the name "American

§ 15) applied to criminal prosecutions, and fee statutes commonly accompanied provisions for liquidated or double damages. E.g., statutes cited supra note 113.

123. Gulf, C. \& S.F. Ry. v. Ellis, 165 U.S. 150, 157 (1897).

124. Id. at 157-59.

125. Dohany v. Rogers, 281 U.S. 362, 368 (1930); Kansas City S. Ry. v. Anderson, 233 U.S. 325 (1914); Missouri, K. \& T. Ry. v. Cade, 233 U.S. 642 (1914); Farmers' \& Merchants' Ins. Co. v. Dobney, 189 U.S. 301 (1903); Fidelity Mut. Life Ass'n v. Mettler, 185 U.S. 308 (1902); Atchison, T. \& S.F.R.R. v. Matthews, 174 U.S. 96 (1899).

126. Atchison, T. \& S.F. Ry. v. Vosburg, 238 U.S. 56, 60-62 (1915) (unconstitutional to make railroad liable for fees in suit for not furnishing cars to shipper, when shipper who does not use cars is not so liable to railroad); for state court cases, see Annot., 73 A.L.R.3d 515 (1976). In two other cases, the Court struck down fee awards to parties who had not prevailed in full, while not invalidating the authorizing statutes. Chicago \& N.W. Ry. v. Nye Schneider Fowler Co., 260 U.S. 35 (1922); St. Louis, I.M. \& S. Ry. v. Wynne, 224 U.S. 354 (1912).

127. Gulf, C. \& S.F. Ry. v. Ellis, 165 U.S. 150 (1897), Brief and Argument for Plaintiff in Error, 3-4.

128. See R. H. SMITh, Justice AND THE POOR (1919).

129. Missouri, K. \& T. Ry. v. Cade, 233 U.S. 642, 647 (1914) (fee up to $\$ 20$ recoverable against any defendant in suit for up to $\$ 200$ for injured livestock, unpaid wages, lost freight, or materials not paid for); Missouri, K. \& T. Ry. v. Harris, 234 U.S. 412, 416 (1914) (same statute upheld against commerce clause and preemption attack). 
Rule."130 The explanatory attempts reflected the rise of academic legal scholarship, and perhaps also a continuing rise in legal fees; they spoke in the prevalent language of social engineering. They sought to evaluate the rule's tendencies to encourage or discourage meritorious litigation, and then to reform it so as to foster the good tendencies and nip the bad ones. Governmental regulation had returned to the scene-albeit at first more to the scholarly than to the political scene. This time the regulators did not seek to restrain the greed of lawyers, as in the Colonial period, but rather to control the frequency and type of litigation.

This kind of analysis was a novelty. As this article has shown, one of the most curious features of the American rule in the nineteenth century was its almost total absence of justification. That lawyers should be paid by their clients rather than by opposing parties seemed so natural that, when attorney fee statutes began to appear, courts usually regarded them as imposing penalties on the acts of the defendant. ${ }^{131}$ A few courts condemned certain fee statutes as penalizing the defendant's decision to litigate. ${ }^{132}$ Another line of cases criticized the assessment of attorney fees as damages against plaintiffs as discouraging their access to the courts. ${ }^{133}$ From such reasoning, the road led to a general assessment of the American Rule as an incentive or disincentive to litigation.

That assessment produced a bizarre variety of opinions, which might go far to justify the view that legal policy analysis is totally arbitrary and manipulable. The first commentators tended to view litigation as an evil, but disagreed as to whether the American rule discouraged ${ }^{134}$ or encouraged it. ${ }^{135}$ Later authors emphasized the encouragement of worthy litigants, but were equally unable to agree as to whether the American rule promoted ${ }^{136}$ or obstructed this goal. ${ }^{137}$ Apparently, one could take any position on the rule, and for any reason. It was not until later that scholars worked out a more discriminating analysis of the rule's effects on claims of varying merit and value. ${ }^{138}$

While commentators battled in the dark about the relative merits of the Amer-

130. The earliest use of the term known to the author is found in Goodhart, supra note 2, at 856 .

131. See supra notes 116,122 , and text accompanying notes 119-26.

132. See St. Louis, I.M. \& S. Ry. v. Williams, 49 Ark. 492, 5 S.W. 883, (1887) (penalty on appealing to court from livestock damage board); Wilder v. Chicago \& W.M. Ry., 70 Mich. 382,38 N.W. 289 (1888); Chicago \& N.W. Ry. v. Nye Schneider Fowler Co., 260 U.S. 35 (1922) (penalty for appeal which defendant won).

133. Straus v. Victor Talking Mach. Co., 297 F. 791, 798-99 (2d Cir. 1924); Ackerman v. Kaufman, 41 Ariz. 110, 15 P.2d 966 (1932); Stringfield v. Hirsch, 94 Tenn. 425, 29 S.W. 609 (1895).

134. A. SEDGWICK, supra note 97 , at 37.

135. M. Storey, The Reform of Legal Procedure 34-36 (1911); First Report of The JudiCial Council of MassachusetTs 63-64 (1925); McCormick, Counsel Fees and Other Expenses of Litigation as an Element of Damages, 15 MINN. L. REv. 619, 641-43 (1931); cf. Calhoun v. Massie, 253 U.S. 170 (1920) (Brandeis, J.) (upholding statute limiting contingent fees in suits against government, since such fees might stimulate lawyers to stir up unjust claims or use improper methods). For the origins of the elite lawyers' campaign against excessive litigation, see $R$. Silverman, supra note 45 , at 78-80.

136. Farmer v. Arabian Am. Oil Co., 379 U.S. 227 (1964); see Goodhart, supra note 2, at 874 (describing but criticizing this view).

137. Goodhart, supra note 2, at 874; Avilla, Shall Counsel Fees Be Allowed?', Cal. ST. B.J. March 1938, at 42; Dayton, Costs, Fees, and Expenses in Litigation, 167 Annals 32 (1933).

138. Mause, Winner Takes All: A Re-Examination of the Indemnity System, 55 IOWA L. REv. 26 (1969); Shavell, Suit, Settlement, and Trial: A Theoretical Analysis Under Altemative Methods for the Allocation of Legal Costs, 11 J. Legal STUd. 55 (1982). 
ican and English rules, judges and legislators began to move toward a third system. Exceptions to the rule grew in number and importance, usually grounded on the same concern with incentives and disincentives which we have already observed.

The "bad faith" doctrine is the clearest example of this concern: it awards attorney fees against parties who litigate in bad faith, for the obvious purpose of deterring illegitimate behavior in the courtroom, and sometimes outside it. ${ }^{139}$ Of course, the granting or denial of costs is a traditional-albeit largely symbolicmethod of punishing improper litigative behavior. ${ }^{140}$ But only during this century did federal courts - at first, only courts of equity-assert any general power to tax attorney fees against obstructive litigants. ${ }^{141}$ It took the concerns of civil rights litigation to give the doctrine any practical importance. ${ }^{142}$ Even today, it has established itself outside the federal courts in only a few states, and there usually by statute. ${ }^{143}$

Incentive reasoning also promoted the expansion of the common fund doctrine. ${ }^{144}$ During the 1930's, commentators and courts lauded common fund fees as an incentive for lawyers to engage in corporate salvage or therapeutics. Professor Hornstein urged with some success that courts ensure an adequate incentive by awarding a percentage of the proceeds as a fee. ${ }^{145}$ With such reasoning to support it, and lawyers eager to push it, the common fund theory spread. ${ }^{146}$ Ultimately, some courts developed the common benefit theory, under which those receiving what the court considered to be benefits from a suit can be required to help pay its expenses. ${ }^{147}$ The benefits need not be monetary, but the payment is. Aside from these doctrinal developments, the rise of the class action expanded enormously the practical impact of the common fund doctrine. Class actions almost automatically give rise to a common fund or benefit when successful, and their supporters promoted both class actions and fee recovery as ways to promote the enforcement of the law through mass litigation. ${ }^{148}$

While the courts were expanding these exceptions to the American rule, legisla-

139. E.g., Vaughan v. Atkinson, 369 U.S. 527, 530-31 (1962) (fees as admiralty damages for willful failure to pay maintenance and cure); Annot., 31 A.L.R. FED. 833 (1977).

140. E.g., Second Report of the Commissioners on Practice and Pleading 41-43 (1849); 1849 N.Y. Laws, ch. 438, §§ 303-22 (amending Field Code to add sanctions).

141. Guardian Trust Co. v. Kansas City S. Ry., 28 F.2d 233 (8th Cir. 1928) rev'd on other grounds, 281 U.S. 1 (1930); Note, Distribution of Legal Expense Among Litigants, 49 YalE L.J. 699 (1940); see Toledo Scale Co. v. Computing Scale Co., 261 U.S. 399 (1923); M. STOREY, supra note 135, at 32-34.

142. See Brewer v. School Bd., 456 F.2d 943, 949-50 (4th Cir. 1972) (citing cases).

143. See Note, Attomey's Fees and the Federal Bad Faith Exception, 29 Hastings L.J. 319 (1977). The pending proposal to award attorney fees against parties who refuse offers of settlement more favorable than what they ultimately obtain in court would greatly expand the use of fee awards to discipline those claiming and defending without cause. See Preliminary Draft of Proposed Amendments to the Federal Rules of Civil Procedure, Rule 68 (Aug. 23, 1983).

144. See supra text accompanying notes 105-10.

145. Hornstein, The Counsel Fee in Stockholders' Derivative Suits, 39 Colum. L. REv. 784 (1939); see In re Osofsky, 50 F.2d 925 (S.D.N.Y. 1931). For more skeptical views, see Note, Allowance of Attorneys' Fees from a Fund in Court, 35 Colum. L. Rev. 740 (1935); Guy, supra note 108.

146. See generally Dawson, supra note 83.

147. E.g., Mills v. Electric Auto-Lite Co., 396 U.S. 375 (1970); see Sprague v. Ticonic Nat'l Bank, 307

U.S. 161 (1939). But see Alyeska Pipeline Serv. Co. v. Wilderness Soc'y, 421 U.S. 240 (1975).

148. E.g., Kalven \& Rosenfield, The Conlemporary Function of the Class Suit, 8 U. CHI. L. REV. 684 (1941); see id. at 715-16, noting the importance of fee incentives for class actions. 
tures were also coming around to the view that at least some litigation was a desirable thing. Fee provisions were attached to a variety of federal statutes, and also to state statutes. ${ }^{149}$ The incredible variety of these statutes precludes most generalization, but demonstrates the decreasing hold of the American rule, and the attraction of fee statutes for lobbies and their lawyers.

In the 1960's, the accumulation of federal fee statutes turned into a deluge which radically transformed the financing of much federal litigation. Virtually all the major civil rights ${ }^{150}$ and environmental ${ }^{151}$ statutes of the 1960's and 1970's included fee provisions. Congress then moved from legislating fees statute by statute to enacting provisions that swept whole areas of litigation into the fee award system. ${ }^{152}$ Such legislation goes far beyond the goal of making access to the courts easier for litigants with strong cases. It embodies a policy of social reform through litigation-especially through litigation that does not yield plaintiffs a financial award from which a contingent fee may be paid. ${ }^{153}$

Although this major expansion of attorney fee recovery originated in Congress, the courts also played a major role in its development. They have read fee statutes broadly, ${ }^{154}$ and they have drawn from them an underlying rationale that civil rights fee statutes should encourage enforcement by "private attorneys general." Hence they should be read to grant fees to virtually all prevailing plaintiffs while denying them to virtually all prevailing defendants. ${ }^{155}$ The rationale and construction so declared have then returned to Congress to influence new legislation, or at least its legislative history. ${ }^{156}$

Legislatures and courts may have joined to promote attorney fee shifting in a broad range of cases, but neither has shown the slightest sign of replacing the American rule with the English rule. Fee statutes have almost invariably been one-sided, holding out the prospect of fees to one class of litigants (usually plaintiffs) while denying it to the other. There has been little effort to expand fee recovery to tort or contract litigation. ${ }^{157}$ Courts, while no more able than their precursors to provide a justification for excluding litigation expenses from costs,

149. For the federal statutes, see $3 \mathrm{H}$. Newberg, Class Actions $\S 7040$ (1977). For surveys of state law, see Ramos v. Lamm, 539 F. Supp. 730, 757-59 (D. Colo. 1982) (Colorado statutes); 4 B. WITKIN, California Procedure 3267-84 (2d ed. 1971 \& Supp. 1981); 8 J. Weinstein, H. Korn \& A. Miller, NEW YORK CIVIL PRACTICE If 8301 (1982); Talmadge, The Award of Attomeys' Fees in Civil Litigation in Washington, 16 Gonz. L. REv. 57 (1980); Note, Statutory Award of Altomey's Fees in Louisiana, 20 LOr. L. REV. 343 (1974); Comment, Court Awarded Attorneys' Fees in Massachusetts, 2 W.N. ENG. L. REV. 361 (1979); Note, State Attorney Fee Shifling Statutes: Are We Quielly Repealing the American Rule? LAw \& CONTEMP. ProBs. Winter 1984, at 321 .

150. E.g., 42 U.S.C. $§ 2000 \mathrm{e}(5)(\mathbf{k})$ (1976) (employment discrimination); 20 U.S.C. $\$ 1617$ (1982) (school desegregation).

151. E.g., 42 U.S.C. $\$ 7607$ (f)(Cum. Supp. V 1981) (Clean Air Act).

152. Civil Rights Attorney's Fee Awards Act of 1976, Pub. L. No. 94-559, 90 Stat. 2641 (1976); Equal Access to Justice Act, Pub. L. No. 96-481, 94 Stat. 2321 (1980).

153. See, e.g., NAACP v. Button, 371 U.S. 415 (1963); O. Fiss, The Civil Rights Injunction (1978). See generally Nussbaum, supra note 5.

154. E.g., Maine v. Thiboutot, 448 U.S. 1 (1980); Bradley v. School Bd., 416 U.S. 696 (1974).

155. E.g., Newman v. Piggie Park Enters., Inc., 390 U.S. 400 (1968); Christiansburg Garment Co. v. EEOC, 434 U.S. 412, 420-22 (1978).

156. E.g., ReP. No. 1011, 94th Cong., 2d Sess., reprinted in 1976 U.S. Code Cong. \& AD. News 5908 157. But Arizona and Hawaii allow fees in contract cases. ARIZ. REV. STAT. ANN. $\$ 12-341.01$ (1982); Hawail Rev. STAT. §607-14 (1968). 
continue to do so except in areas where they or the legislature have decided to provide an incentive for litigation. ${ }^{158}$ In some states, courts and lawyers have even sought to constrict opportunities for fee recovery. ${ }^{159}$ Apparently, only a few academics support the English rule. ${ }^{160}$

Perhaps we can best explain this pattern of development by returning to the origins of the American rule. Lawyers had no reason to oppose low cost recovery once they were free to recover substantial fees from clients, ${ }^{161}$ but that could only be true while there were enough paying clients to support the bar. In recent decades, the size of the bar has risen, and, as Professor Abel has pointed out, lawyers have pressed with some success for measures which expand the demand for lawyers. ${ }^{162}$ At the same time, litigation expenses have soared beyond most people's capacity to pay. One response is to finance litigation out of the pockets of governmental or corporate parties, precisely those litigants who pay typical attorney fee awards. ${ }^{163}$ But lawyers who bring traditional suits do not need these aids, since they are paid by businesses or (in the case of tort plaintiffs' lawyers) by contingent fees. Lawyers who do not need a fee statute will not lobby for one. Indeed, they may oppose it, since it necessarily involves public disclosure of legal bills and their evaluation by a court. ${ }^{164}$ The clients of such lawyers are also unlikely to press for fee statutes. If they are businesses, they will expect to pay fee awards at least as often as they recover them; if they are individual tort plaintiffs, they are unorganized, and plan to pay their lawyers out of their recoveries rather than out of their pockets. For these reasons, fee recovery has not spread throughout our legal system.

\section{VI \\ The American Rule Abandoned?}

Surveying the past does not ensure that one can predict the future. It may,

158. E.g., Summit Valley Indus. v. Local 112, United Bhd. of Carpenters, 456 U.S. 717 (1982); Alyeska Pipeline Serv. Co. v. Wilderness Soc'y, 421 U.S. 240 (1975); F.D. Rich Co. v. Industrial Lumber Co., 417 U.S. 116 (1973).

159. IDAHO CODE § 54(3)(1) (1979), cutting back 1976 Idaho Sess. Laws ch. 349; Lynch, The New Jersey Supreme Court and the Counsel Fees Rule: Procedure or Substance and Remedy? (pts. 1 \& 2), 4 SETON HALL L. REv. 19 (1972), 4 Seton Hall L. REv. 421 (1973); see Note, Award of Altomey's Fees in Alaska: An Analysis of Rule 82, 4 U.C.L.A.-ALASKA L. REV. 129 (1974) (describing bar criticism of rule allowing prevailing party to recover fees).

160. E.g., Ehrenzweig, Reimbursement of Counsel Fees and the Great Society, 54 CALIF. L. REV. 792 (1966); Kuenzel, The Altomey's Fee: Why Not a Cost of Litigation?, 49 Iowa L. REV. 1975 (1963).

161. See supra text accompanying notes 23-55.

162. Abel, Why Does the ABA Promulgate Ethical Rules?, 59 TEx. L. REv. 639, $657-62$ (1981)

163. But why cannot these powerful agencies and corporations prevent passage of fee statutes which force them to pay lawyers who litigate against them? One possible answer is that economic self-interest does not explain everything. The prospect of hiring lawyers may make the bar support fee statutes or stand neutral to them. The neutral stand, however, will only assure a serious hearing for the statutes by neutralizing the opposition of potential defendants. Whether the statutes pass depends on other factors including public opinion, practicalities, and the legislative sense of justice.

164. The American Bar Association, for instance, has approved fee shifting proposals only to the extent that they facilitate litigation which would otherwise be financially impractical. See Sands, Attomeys Fees as Recoverable Costs, 63 A.B.A. J. 510 (1977); 102 A.B.A. ANN. REP. 518-19, 783-85 (1977); The American Bar Association Position, 64 A.B.A. J. 862 (1978). 
however, enable one to point to trends that should be important in the years to come. Four such current trends are apparent.

First, though fee statutes will undoubtedly continue to be passed, there is no likelihood that the English rule of almost automatic fee recovery will be any more successful in this country in the future than it has been in the past. We will continue to evolve a system of our own in which considerations of policy and politics determine which lawsuits and lawyers will be encouraged. ${ }^{165}$

What will that system be like? Perhaps a glimpse of it can be caught in the Equal Access to Justice Act, ${ }^{166}$ with its elaborate provisions for fee awards against the government in lawsuits and contested agency proceedings in which the government loses and cannot show that its position was substantially justified. The bipartisan acclamations which accompanied the passage of this Act show that there is little political mileage nowadays in opposing fee legislation. ${ }^{167}$ They also show that fee legislation is no longer a purely liberal cause. The Act's originators were mainly conservatives anxious to encourage businesses to litigate against the federal government. ${ }^{168}$ Private attorneys general, it seems, are now to fight with the real attorney general, not to supplement him. Most important of all, the Act abandons the pro-plaintiff tilt of recent statutes: a party who prevails against an unjustified government position can recover a fee regardless of whether she began the proceeding or was its victim. One rationale for this is that such a prevailing party has vindicated important public policies by enforcing the law-but this is more or less true of any successful litigant.

The message of the Act may be that Congress is now willing to award fees to a relatively poor party who prevails against a wealthy institutional litigant. ${ }^{169}$ That message would be consistent with past practice under federal fee statutes-which, whatever their purported neutrality, have usually benefited those suing corporations and governments - as well as with the reiterated concern for poor litigants expressed in past discussions of the American rule and its exceptions. ${ }^{170}$ The message would also accord with the development of governmental funding for legal services. ${ }^{171}$ It seems safe to predict that we will hear more of fee awards to poor parties who prevail against rich ones. ${ }^{172}$ And there are already some signs of

165. See Rowe, The Legal Theory of Altomey Fee Shifing: A Critical Overview, 1982 DukE. L.J. 651.

166. Pub. L. No. 96-481, §§ 203-04, 94 Stat. 2321 (1980).

167. 125 CONG. REC. S10914-24 (1979) and 126 CONG. ReC. S13873-76 (1980) (Senate nondebates); see 26 Cong. ReC. H $10212-31$ (1980) (House debates). Contra Sylvester, OMB's New Assault on Legal Fees, Nat'l L.J., Nov. 29, 1982, at 1, col. 4; Hearing on S. 585 before Subcomm. on the Constitution of the Senate Judiciary Comm., 97th Cong., 2d Sess. (statement of Senator Hatch proposing that state and local governments be allowed a good faith defense against the imposition of attorney fees).

168. See Award of Attomey's Fees Against the Federal Covermment: Hearings before the Subcommittee on Courts, Civil Liberties, and the Administration of Justice of the House Judiciary Committee, 96th Cong., 2d Sess. 15-29, 56-58 (1980).

169. Only a party within specific wealth limitations may recover under the Act. 5 U.S.C. $\S 504$ (b)(1)(B) (1982); 28 U.S.C. $\$ 2412$ (d)(2)(B) (Cum. Supp. V 1981). See also the Act's declaration of policy, Pub. L. No. 96-481, § 202, 94 Stat. 2321 (1980).

170. E.g., 42 U.S.C. $\$ 3612$ (c)(1976); Fleischmann Distilling Corp. v. Maier Brewing Co., 386 U.S. 714, 718 (1967); Goodhart, supra note 2, at 874-76.

171. See generally E. JOHNSON, JUSTICE AND REFORM (1974).

172. See Comment, Financial Barriers to Litigation: Attomey Fees and the Problem of Legal Access, 46 ALBANY L. REv. 148 (198I). 
a movement to compensate litigants who do not prevail but who represent a group whose members could otherwise not afford to be heard. ${ }^{173}$

Second, the multiplication of fee awards will undoubtedly lead to still greater concern with the size of fees, and the procedures for awarding them. Already, within the last decade, this concern has led to the assessment of fees based on the multiplication of the hourly value of each lawyer's time by the hours contributed, and computed on the basis of detailed evidence and court findings. ${ }^{174}$ This has somewhat reduced fees in cases in which damages are recovered, ${ }^{175}$ while perhaps increasing them in injunctive cases. It has also, unfortunately, led to a considerable increase in the time and money devoted to litigating fees issues, and apparently to efforts by lawyers to grab a piece of the pie by jumping into class actions and other common fund cases and multiplying their hours. ${ }^{176}$

To some extent, these problems are unavoidable. Lawyers will always claim that substantial fees are necessary to provide an adequate incentive for cases to be brought, and courts will have to pay a price in more complex procedures for their efforts to bring fee levels under control. If we are lucky, we will follow the English tendency to develop standardized tariffs and specialized personnel for the calculation of fees. ${ }^{177}$ Whatever system we adopt, lawyers will no doubt find ways to turn it to their own advantage.

Setting the level of fees, however, is more than a matter of frugality and procedure. It raises questions which go to the heart of the reasons for awarding fees. Just how much litigation do we want to stimulate? How can fee levels be set so that lawyers will accept the right cases as indicated by their probability of success, cost of litigation, likely benefits, or other criteria? Did (and should) Congress wish to create incentives of equal power for litigation under each of the many statutes it has equipped with attorney fee provisions? When it set out to encourage litigation under these statutes, did it mean to take resources away from more traditional litigation, or to increase the share of our gross national product that goes to financing lawyers and their activities? Scholars are beginning to ask these questions. ${ }^{178}$ More will certainly be heard of them.

Third, the growth of fee recovery will affect the economic structure of the legal profession. The growth of the American rule was linked to the ability of lawyers to recover substantial fees from paying clients. In the past, fee shifting has been too

173. E.g., Sierra Club v. Gorsuch, 672 F.2d 33 (D.C. Cir. 1982), rev'd, 51 U.S.L.W. 5132 (1983). Boyer, Funding Public Participation in Agency Proceedings: The Federal Trade Commission Experience, 70 GEO. L.J 51 (1981); Public Interest LaW (B. Weisbrod ed. 1978).

174. E.g., 28 U.S.C. $\S 2412$ (d) (Cum. Supp. V 1981)(Equal Access to Justice Act); Lindy Bros. Builders v. American Radiator \& Standard Sanitary Corp., 487 F.2d 161 (3d Cir. 1973); A. MiLleR, Attorneys' FeEs in Class ACtions 60-64 (1980).

175. See Mowrey, Attomey Fees in Securities Class Actions and Derivative Suits, 3 J. CORP. L. 267, 343-45 (1978); Development-Altomey Fee Awards in Antitrust and Securities Class Actions, 6 Cl.Ass ACTION REP. 82 (1982).

176. See In re Fine Paper Antitrust Lit., 98 F.R.D. 48 (E.D. Pa. 1983); Coffee, Rescuing the Private Attomey General: Why the Model of the Lawyer as Bounty Hunter is Not Working, 42 MD. L. REV. 215 (1983).

177. I Royal Commission on Legal Services, Final Report, CMd., 1, No. 7648, at 550-56, 56772 (1979).

178. Shavell, The Social versus the Private Incentive to Bring Suit in a Costly Legal System, 11 J. LEGAL STUD. 333 (1982); Leubsdorf, The Contingency Factor in Attomey Fee Awards, 90 YALE L.J. 473 (1981). 
peripheral to dislodge the relationship between paying client and lawyer from its preeminent role in shaping the profession. This situation is now beginning to change. The resulting trends will probably reinforce other forces supporting increased governmental regulation of the bar. We have not yet reached the situation of England, where more than half the income of barristers comes from civil and criminal legal aid cases, ${ }^{179}$ but we are at least edging in that direction.

One small sign of this development has already appeared in the increased willingness of lawmakers to treat the lawyer as an actor independent from his client, and to seek to control his conduct. It is not surprising that courts offered carrots to lawyers for this purpose long before they resorted to sticks. Soon after it created the common fund doctrine, the Supreme Court allowed a victorious plaintiff's lawyer to benefit from it by recovering a fee in addition to what his client had agreed to pay him. ${ }^{180}$ In recent years, this doctrine has blossomed to allow legal services offices to recover fees even though they are legally forbidden to charge their own clients. Courts have made it quite clear that these awards are for the law office and not the client. ${ }^{181}$ But the stick has now joined the carrot. Courts and legislators have started to impose fee liability on lawyers rather than clients, in order to deter bad faith litigation more effectively. ${ }^{182}$ As these trends indicate, judges rather than clients control the pay of lawyers in fee award cases, and can be expected to act accordingly. This may mitigate the excesses of the adversary system, while introducing some new excesses. ${ }^{183}$

Legislatures also will find that their decisions to stimulate certain kinds of suits lead to important regulatory choices. The passage of a fee award statute implies decisions about how to encourage litigation. Under such a statute, litigation will be conducted by lawyers approved by clients, often by members of the private bar. These lawyers will not be paid when they lose, and will recover fairly large fees from the losing defendants when they win. These decisions are not inevitable. Congress might have chosen-and in fact has done so in other areas-litigation by Legal Services Corporation lawyers representing private clients, Justice Department lawyers representing governmental agencies, or other kinds of publicly financed litigation. ${ }^{184}$ The lawyers might receive a salary or a standard hourly

179. Royal Commission on Legal Services, supta note 177 , at 520 .

180. Central R.R. \& Banking Co. v. Pettus, 113 U.S. 116 (1885). For the later development of the theory that lawyers (as opposed to clients) should be given incentives to undertake fund cases, see supra text accompanying notes $144-48$.

181. E.g., Rodriguez v. Taylor, 569 F.2d 1231 (3d Cir. 1977). The doctrine that lawyers can recover fees for time devoted to establishing their right to fees reflects similar ideas. E.g., Prandini v. National Tea Co., 585 F.2d 47 (3d Cir. 1978).

182. 28 U.S.C. $\S 1927$ (1976), as amended by Pub. L. No. 96-349, § 3, 94 Stat. 1154 (1980); Roadway Express, Inc. v. Piper, 447 U.S. 752 (1980); Maneikis v. Jordan, 678 F.2d 720 (7th Cir. 1982); Second Report of the Special Committee for the Study of Discovery Abuse, 92 F.R.D. 137, $147-48$ (1980). But see Bauguess v. Paine, 22 Cal. 3d 626, 586 P.2d 942, 150 Cal. Rptr. 461 (1978) (rejecting liability as tending to intimidate the bar); Friedman v. Dozorc, 412 Mich. 873, 312 N.W.2d 585 (1981) (rejecting malicious prosecution liability of plaintiff's lawyer to medical malpractice defendant). Assessing fees against lawyers is well established in England. Myers v. Elman, [1940] A.C. 282 (H.L.); SAYER, supra note 17, at 309-13.

183. E.g., Richard v. Internal Revenue Service, 519 F. Supp. 924 (N.D. Ill. 1979) (fee denied because lawyer insulted judge).

184. E.g., 15 U.S.C. $\$ \S 15 \mathrm{c}-15 \mathrm{~g}$ (1982)(parens patriae antitrust suits by states); N.J. STAT. ANN. $\S \S 52: 27 \mathrm{E}-1$ to $27 \mathrm{E}-47$ (West 1955) (Public Advocate to represent public interest). 
wage, rather than a fee contingent on success. And their costs might be borne by taxpayers, litigants in general, or the bar, instead of by losing defendants. ${ }^{185}$

Although the various permutations of these possibilities raise questions for economic and policy analysis, we can expect that their use or neglect will continue to be governed largely by political factors. Such factors may well explain the rise of attorney fee statutes, as opposed to other litigation incentives. Fee statutes gratify at least some members of the practicing bar, call for no immediate Congressional appropriation, ${ }^{186}$ and leave at least some of the blame for the resulting litigation on private clients and private lawyers. That may well be why Congress has authorized fee recovery for school desegretation plaintiffs, while forbidding the Legal Services Corporation to take desegregation cases and constricting the government's administrative desegregation powers. ${ }^{187}$ As the impact of fee statutes is recognized, and as the government itself begins to pay fee awards, such statutes will become more controversial. ${ }^{188}$ Perhaps legislators then will become more interested in arrangements which save money by channeling litigation to specialized legal services offices using salaried lawyers.

Fourth, and finally, as federal courts and legislators continue to confront the repercussions of the fee award revolution, that revolution will affect litigation in state courts. Indeed, this is already happening, ${ }^{189}$ with some nudging from federal authorities. ${ }^{190}$ The result will be that fee awards will cease to be of concern only to a limited, federal, public interest bar and its opponents. Unless the trends of the last century suffer an abrupt reversal, the trial bar as a whole will no longer be able to consider client payments and contingent fees as the only significant source of litigation financing.

It is appropriate enough that new modifications of the American rule should return to the state courts. After all, that is where the rule started, almost two hundred years ago. It remains to be seen whether modifications will lead to a system

185. Recent Massachusetts legislation charges all plaintiffs a filing fee for the support of legal services organizations. 1982 Mass. Acts ch. 609. For support by lawyers, see, e.g., Christensen, The Lawyer's Pro Bono Publico Responsibility, 1981 AM. B. Found. RESEARCH J. 1.

186. Legislatures have long perceived this advantage. $1860 \mathrm{Cal}$. Stat. ch. $172, \S 7$ (district attorney suing for delinquent taxes to be paid by fee award against losing defendants).

187. 20 U.S.C. $\$ 1617$ (1982) (fee statute); 42 U.S.C. $§ 2996 f(b)(9)$ (1977) (Legal Services Corporation prohibition); Brown v. Califano, 627 F.2d 1221 (D.C. Cir. 1980); Orfield, Congress, the President, and AntiBusing Legislation, 1966-74, 4 J. L. \& EvUC. 81 (1975).

188. See Copeland v. Marshall, 641 F.2d 880, 908 (D.C. Cir. 1980) (Wilkey, J., dissenting); Taylor, Reagan Stalks Public Interest Lawyers' Fees, N.Y. Times, Feb. 19, 1982, at 14.

189. E.g.; Calif. CiV. PrOC. CODE $\$ 1021.5$ (West 1980) (fee award where appropriate in action enforcing important right affecting the public interest when large class is benefitted); WASH. REV. CODE $\$ \S 4.84 .250-80$ (1972) (prevailing party recovers fee in damage action for up to \$5,000). N.Y. CIV. PRAC. R. 909 (class action fee award); Consumers Lobby Against Monopolies v. PUC, 25 Cal. 3d 891, 603 P.2d 41, 160 Cal. Rptr. 124 (1979) (common fund doctrine in administrative proceeding); Fiorito v. Jones, 72 Ill. 2d 73, 377 N.E.2d 1019 (1978) (hourly rate approach to fee assessment). There are at least 2,000 state fee-shifting statutes currently existing. Note, State Attomey Fee Shifing Statutes: Are We Quietly Repealing the American Rule? LaW and Contem. Probs. Winter 1984, at 321.

190. Maine v. Thiboutot, 448 U.S. 1 (1980) (fees recoverable under 42 U.S.C. $\$ 1988$ in state court suit under 42 U.S.C. $\$ 1983$ enforcing federal statutory right against state officers); see New York Gaslight Club, Inc. v. Carey, 447 U.S. 54 (1980) (federal suit to recover fees for state administrative employment discrimination proceeding); 16 U.S.C. $\$ 2632$ (1977) (fees for consumer participants in state public utility proceedings). 
which judges and legislators are more willing to defend than past judges and legislators were to defend the system they created. 